HYDRAULIC AND SALINITY CHARACTERISTICS OF THE TIDAL REACH OF THE PEACE RIVER, SOUTHWESTERN FLORIDA

By Yvonne E. Stoker, S.E. Henderson, and Benjamin F. McPherson

U.S. GEOLOGICAL SURVEY

Water-Resources Investigations Report 88-4162

Prepared in cooperation with the

FLORIDA DEPARTMENT OF ENVIRONMENTAL REGULATION

Tallahassee, Florida 1989 


\section{DEPARTMENT OF THE INTERIOR}

MANUEL LUJAN, JR., Secretary

\section{U.S. GEOLOGICAL SURVEY}

Dallas L. Peck, Director

For additional information write to:

District Chief

U.S. Geological Survey

Suite 3015

227 North Bronough Street

Tallahassee, Florida 32301
Copies of this report may be purchased from:

U.S. Geological Survey

Books and Open-File Reports

Federal Center, Building 810

Box 25425

Denver, Colorado 80225 


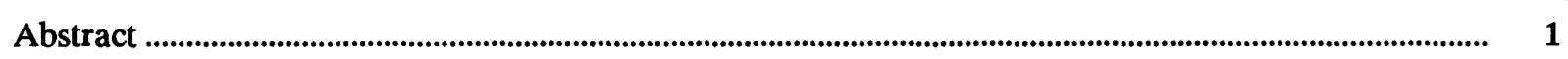

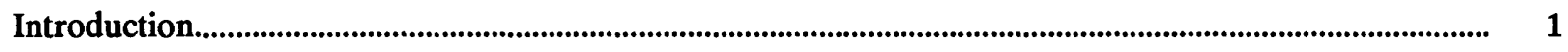

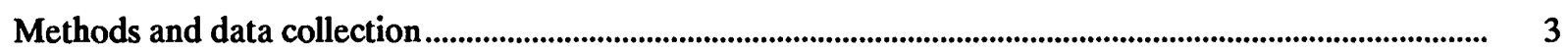

Freshwater inflow and tidal stage, velocity, and discharge................................................................ 3

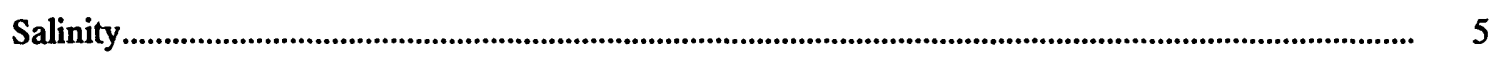

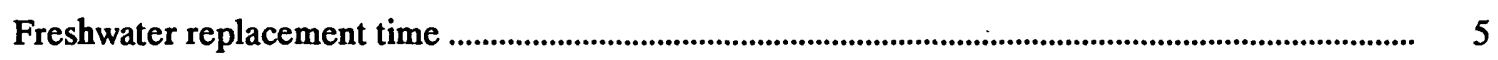

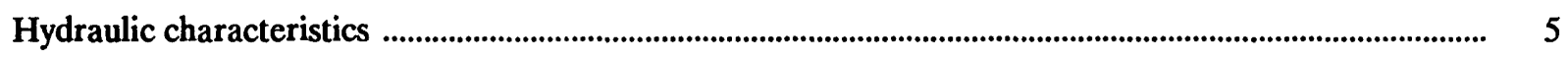

Bathymetry and flood-plain characteristics............................................................................... 5

Tributary and ground-water inflows.............................................................................................................. 6

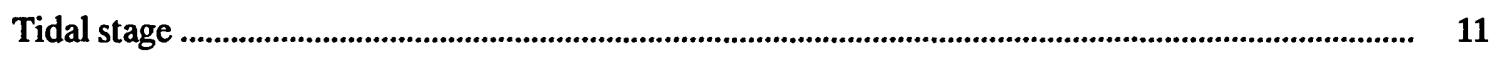

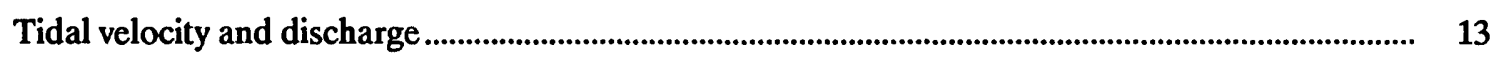

Salinity characteristics .......................................................................................................................................... 16

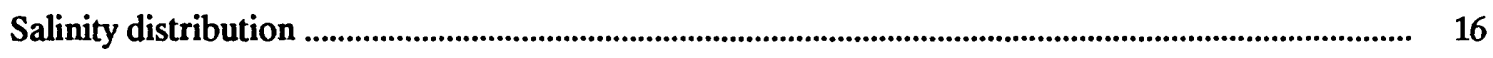

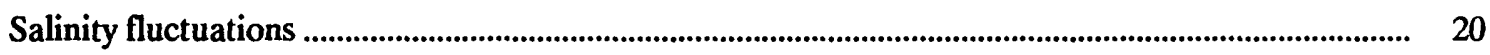

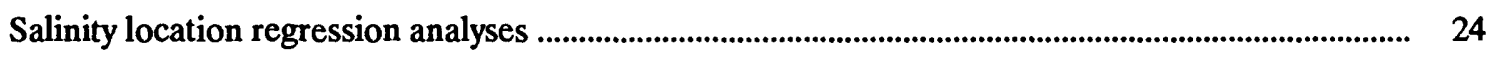

Salinity locations estimated from specific conductance at fixed gages........................................ 24

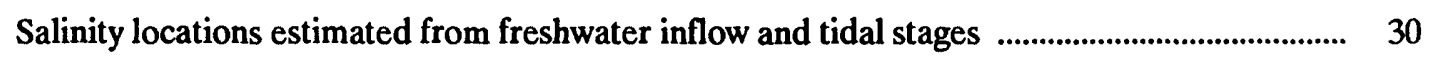

Salinity stratification regression analyses .................................................................................... 33

Freshwater replacement time .................................................................................................................... 34

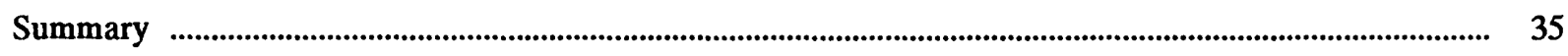

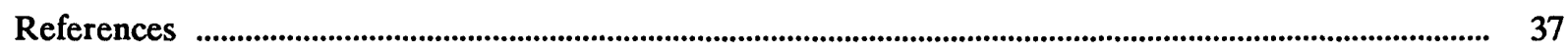

\section{ILLUSTRATIONS}

Figures 1.-2. Maps showing:

1. Peace River basin .

2. Tidal Peace River, location of the tide and specific-conductance gages, and field measurement sites

3. Cross section showing the thalweg of the tidal Peace River ...................................................... 6

4. Selected cross sections of the tidal Peace River ......................................................................... 7

5.-21. Graphs showing:

5. Discharge for the four gaging stations tributary to the tidal Peace River, 1982-86

6. Flow-duration curves for inflow to the tidal Peace River for climatic years 1966-85 and for 1983-85

7. Magnitude and frequency of annual low flow into the tidal Peace River..................... $\quad 10$

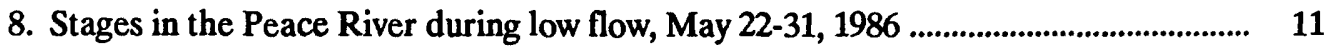

9. Stages in the Peace River during high flow, September 6-15, 1985 .............................. 12

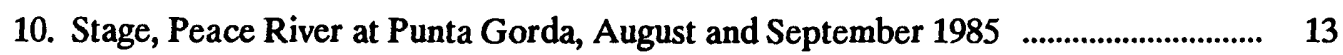

11. Point velocities at State Road 761, gaged daily mean inflow above State Road 761, and daily mean discharge at State Road 761 ............................... 14 


\section{ILLUSTRATIONS--Continued}

Figures 5.-21. Graphs showing--continued:

12. Duration of instantaneous mean river velocities at river mile 18.9,

State Road 761, for December 1985 through May 1986

13. Stage and discharge at State Road 761 for July 10-11, 1984, and February 1, 1985

14. Stage and discharge at State Road 761 for May 7 and December 11-12, 1985

15. Stage and discharge in main channel at river mile $\mathbf{1 1 . 5}$ and in Hunter Creek on July 12, 1984

16. Field measurements of near-surface and near-bottom salinity as a function of river mile

17. Daily mean salinity at the river gage sites.

18. Stage and near-surface and near-bottom salinity at Punta Gorda, September 20-26, 1985

19. Difference between near-surface and near-bottom salinity and stage at Punta Gorda, August 9-12,1985

20. Duration curves for salinity at three continuous recording gages on the tidal Peace River, April 1983 through December 1985

21. Duration curves for the estimated locations of the bottom 1-part-per-thousand salinity and the surface 10-parts-per-thousand salinity, April 1983 through December 1985

22.-23. Maps showing:

22. Fifty-percent frequency locations of the estimated daily high-tide salinities, April 1983 through December 1985

23. Ten-percent frequency locations of the estimated daily high-tide salinities, April 1983 through December 1985

24.-26. Graphs showing:

24. Effects of reductions in the 2-year low flows on the locations of the high-tide surface salinity of 0.5 -part-per thousand

25. Difference between surface and bottom salinity at river mile 0 as a function of 5-day sums of discharge at the Peace River at Arcadia

26. Relation between freshwater replacement time and monthly average freshwater inflow in the tidal Peace River

\section{TABLES}

Table 1. Ranges in velocity and discharge measured at river miles 18.9 and 11.5 in the tidal Peace River

2. Results of regression analyses relating salinity locations to daily mean conductance

3. Regression equations relating salinity locations to freshwater inflow and daily mean stage in the tidal Peace River

4. Range of discharges and tides used in regression analyses 


\section{CONVERSION FACTORS}

The inch-pound units used in this report may be converted to metric (International System) units by the following factors.

Multiply inch-pound unit

inch (in.)

inch per year (in/yr)

foot (ft)

foot per second $(\mathrm{ft} / \mathrm{s})$

mile (mi)

square foot $\left(\mathrm{ft}^{2}\right)$

square mile $\left(\mathrm{mi}^{2}\right)$

cubic foot $\left(\mathrm{ft}^{3}\right)$

cubic foot per second

$\left(\mathrm{ft}^{3} / \mathrm{s}\right)$

mile per hour $(\mathrm{mi} / \mathrm{h})$

nautical mile per hour (knot)
By

25.4

2.54

0.3048

0.3048

1.609

0.09294

2.590

0.02832

0.02832

1.609

1.8532
To obtain metric unit

millimeter (mm)

centimeter per year $(\mathrm{cm} / \mathrm{yr})$

meter (m)

meter per second $(\mathrm{m} / \mathrm{s})$

kilometer (km)

square meter $\left(\mathrm{m}^{2}\right)$

square kilometer $\left(\mathrm{km}^{2}\right)$

cubic meter $\left(\mathrm{m}^{3}\right)$

cubic meter per second

$$
\left(\mathrm{m}^{3} \mathrm{~s}\right)
$$

kilometer per hour $(\mathrm{km} / \mathrm{h})$

kilometer per hour $(\mathrm{km} / \mathrm{h})$

Temperature in degrees Fahrenheit $\left({ }^{\circ} \mathrm{F}\right)$ can be converted to degrees Celsius $\left({ }^{\circ} \mathrm{C}\right)$ as follows:

$$
{ }^{\circ} \mathrm{F}=1.8^{\circ} \mathrm{C}+32
$$

Sea Level: In this report, "sea level" refers to the National Geodetic Vertical Datum of 1929 (NGVD of 1929)--a geodetic datum derived from a general adjustment of the first-order level nets of both the United States and Canada, formerly called "Sea Level Datum of 1929."

\section{Additional Abbreviations}

microsiemens per centimeter

parts per thousand $\mu \mathrm{S} / \mathrm{cm}$

ppt 


\title{
HYDRAULIC AND SALINITY CHARACTERISTICS OF THE TIDAL REACH OF THE PEACE RIVER, SOUTHWESTERN FLORIDA
}

\author{
By Yvonne E. Stoker, S.E. Henderson, and Benjamin F. McPherson
}

\begin{abstract}
The tidal reach of the Peace River in southwestern Florida extends about 26 miles upstream from Charlotte Harbor and has characteristics that include flow-direction reversals, low velocities, and salinity gradients that change with freshwater inflow, tides, and wind. Flow reversals generally occur on each tide throughout most of the tidal reach, with their upstream limit determined primarily by the amount of freshwater inflow and the range in tide. Flow reversals occur at river mile 18.9 whenever freshwater inflows are less than about 1,000 cubic feet per second. Velocities were less than 0.3 foot per second more than half the time at river mile 18.9. The volume of flood and ebb tidal flows in the midreach of the tidal river (mile 11.5) on July 12-13, 1984, was about five times the volume of flood and ebb tidal flows near the upstream end of the tidal reach (mile 18.9) on July 10-11, 1984. Salinity varied along the 26-mile river reach, across the channel and with depth, depending upon complex patterns of flow, freshwater runoff, wind, tide, and salinity in Charlotte Harbor. Daily variations in salinity increased downstream, and variations were larger near the surface than near the bottom. Regression analyses indicated that the location of the 0.5-part-per-thousand salinity will move upstream more than 2 river miles if low flows are reduced by 50 percent. Freshwater flushing of the lower 20-mile tidal reach, approximated from freshwater replacement time, varied from about 2 days during high freshwater nunoff to 40 days during extreme or extended periods of low flows.
\end{abstract}

\section{INTRODUCTION}

The Peace River in southwestern Florida is the principal source of freshwater to Charlotte Harbor. From its headwaters among a group of lakes east of Lakeland, the river flows southward about 75 miles and drains $2,350 \mathrm{mi}^{2}$ of central Florida (fig. 1). Land-surface altitudes range from over 200 feet above sea level near its headwaters to sea level at its mouth. The upper reach of the river is heavily impacted by municipal, industrial, and agricultural development. Flow and water quality are directly affected by six municipalities and by extensive phosphate mining and ranching activities. The basin downstream of Arcadia is relatively undeveloped, but development is expected to increase (Hammett, 1988).

The tidal reach of the Peace River (hereafter referred to as the tidal river) is the connecting link between the inflowing freshwater and the estuarine water of Charlotte Harbor. Freshwater inflows from the river help in maintaining estuarine conditions in the harbor. The tidal river extends about 26 miles upstream from the harbor and is characterized by flow-direction reversals, low velocities during parts of the tidal cycle, and salinity gradients that vary with freshwater inflow, tides, harbor salinity, and wind. The tidal river is an area of intense physical, chemical, and biological processes where the characteristics of the water are modified before flowing into the harbor.

Information about salinity distributions, hydraulics, and freshwater flushing in the tidal Peace River is needed to assess environmental changes that may occur in Charlotte Harbor as a result of decreased freshwater inflow or altered water quality that could take place with further development in the basin. The purpose of this report is to summarize information on hydraulics, salinity distribution, and freshwater flushing in the tidal Peace River, not only for use in management decisions, but also as a reference source for future estuarine studies. The report was prepared by the U.S. Geological Survey in cooperation with the Florida Department of Environmental Regulation and is based primarily on data collected during 1982-86 as part of the Charlotte Harbor estuarine investigation. The report includes information on river bathymetry, flood-plain 


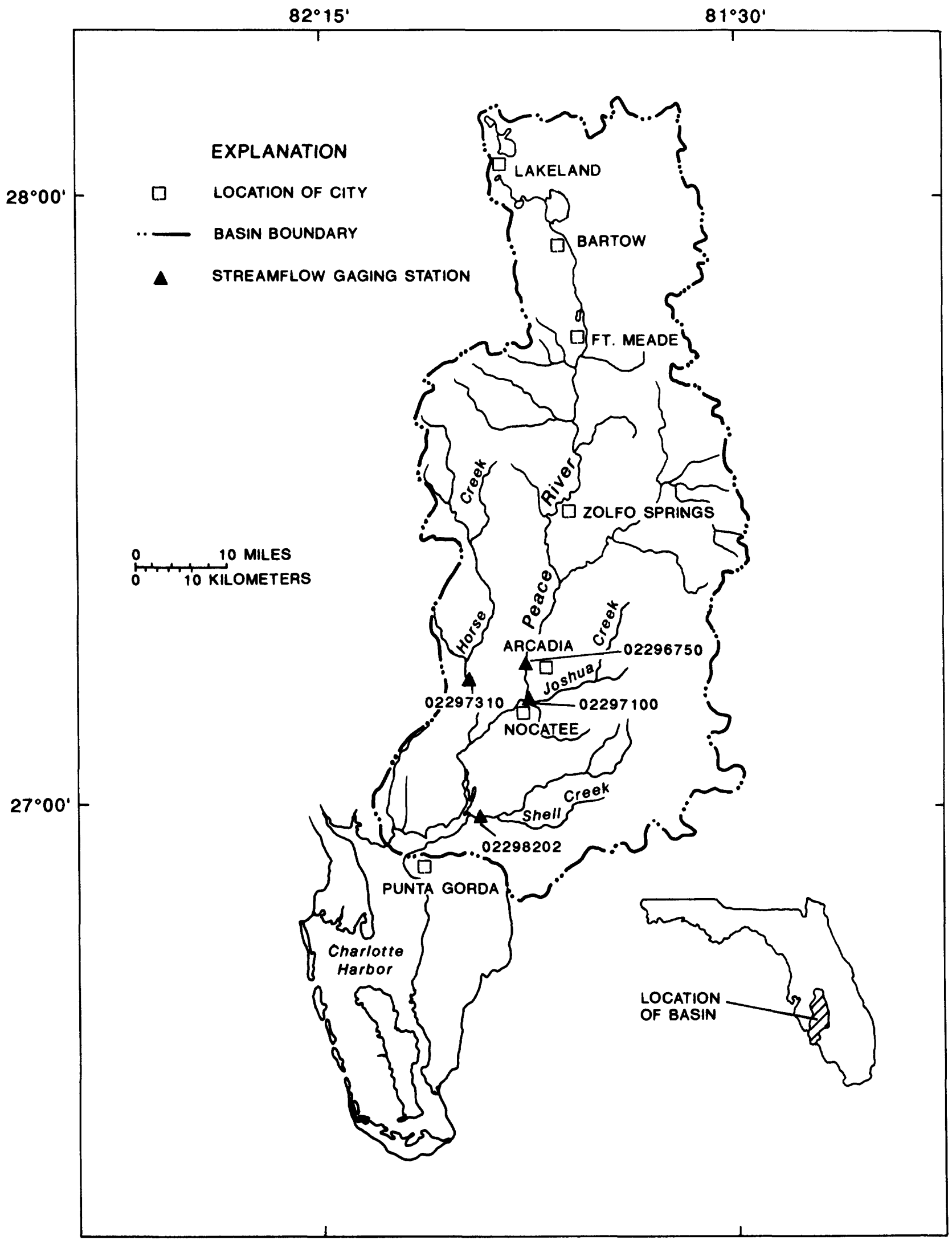

Figure 1.--Peace River basin. 
characteristics, tributary and ground-water inflows, tidal stage, velocity and discharge, salinity distribution and stratification, and freshwater replacement time.

\section{METHODS AND DATA COLLECTION}

\section{Freshwater Inflow and Tidal Stage, Velocity, and Discharge}

Freshwater inflow to the tidal Peace River was measured at Arcadia and at three discharge gaging stations on the major tributaries (fig. 1). A stage-discharge relation was established for each station and rating tables were prepared. The daily mean discharge was computed from continuous water-level recorders and the rating tables.

Continuous tide-stage records were available from four stations during the course of this study (fig. 2). Records from these stations were evaluated to determine lag times and changes in amplitude of tidal waves and were used in salinity regression models. Temporary stage recorders were installed in the upper reaches of the tidal river to determine the extent of tidal effects.

Tidal velocity and discharge data were collected at two locations on the tidal river, one near the upstream end of tidal flow at State Road 761 (river mile 18.9) and the other near the midtidal river at river mile 11.5. Discharge was determined for individual measurements using Price current meters and standard U.S. Geological Survey streamflow measuring techniques. Point velocities were measured at a fixed location throughout the tidal cycles and were plotted versus the mean velocity of each measurement to develop a point-velocity versus mean-velocity rating. This, in conjunction with a stage-area rating, allowed interpolation of discharge between individual discharge measurements.

The most extensive data-collection effort was at State Road 761 where discharge measurements were made throughout a complete tidal cycle on July 10-11, 1984, and in 1985 on February 1, May 7, and December 11-12. A recording electromagnetic velocity meter also was installed at State Road 761 to measure point velocities. The meter measured velocity at 5-minute intervals between December 1985 and May 1986. Discharge over a tidal cycle was measured at river mile 11.5 in the main channel and in Hunter Creek on July 12-13,
1984, and in the main channel on December 11-12, 1985.

\section{Salinity}

Field measurements of specific conductance (conductance standardized to $25^{\circ} \mathrm{C}$ ) were made along the tidal reach of the Peace River (fig. 2) on 15 occasions during the period June 1982 through September 1985. Measurements began in the harbor and continued upstream in the river until freshwater (about $400 \mu \mathrm{S} / \mathrm{cm}$ ) was encountered. The measurements were made at the stream center near the surface, near the bottom, and at selected intervals to define the vertical conductance profile. Eleven of the sampling events were made at or near high tide during a variety of freshwater inflow conditions. Four were at low tide.

The Environmental Quality Laboratory, Inc. (EQL), collected specific-conductance data at 15 sites in the tidal Peace River during high tide (fig.2). Bimonthly measurements made by the EQL from January 1983 through February 1985 were included in the data analyses.

Three specific-conductance recorders were installed in the tidal Peace River: the Peace River Heights gage at river mile 15.8, the Harbour Heights gage at river mile 9.7, and the Punta Gorda gage on the downstream side of the U.S. Highway 41 bridge at river mile 3.9 (fig. 2). These gages recorded specific conductance at 15-minute intervals and were operated from April 1983 through December 1985. The conductance probes were positioned near the river bottom and were inspected and calibrated routinely. An additional conductance probe was installed near the surface at the Punta Gorda gage. This probe was operated intermittantly during the study to provide information on conductance stratification at this site.

Statistical analyses of the data were made using field and gaged specific conductances. Final results were converted to salinity in parts per thousand using a U.S. Geological Survey computer program (R.L. Miller, U.S. Geological Survey, written commun., 1985). For consistency, most results are presented in terms of salinity, although computations may have been made using specific conductance. 


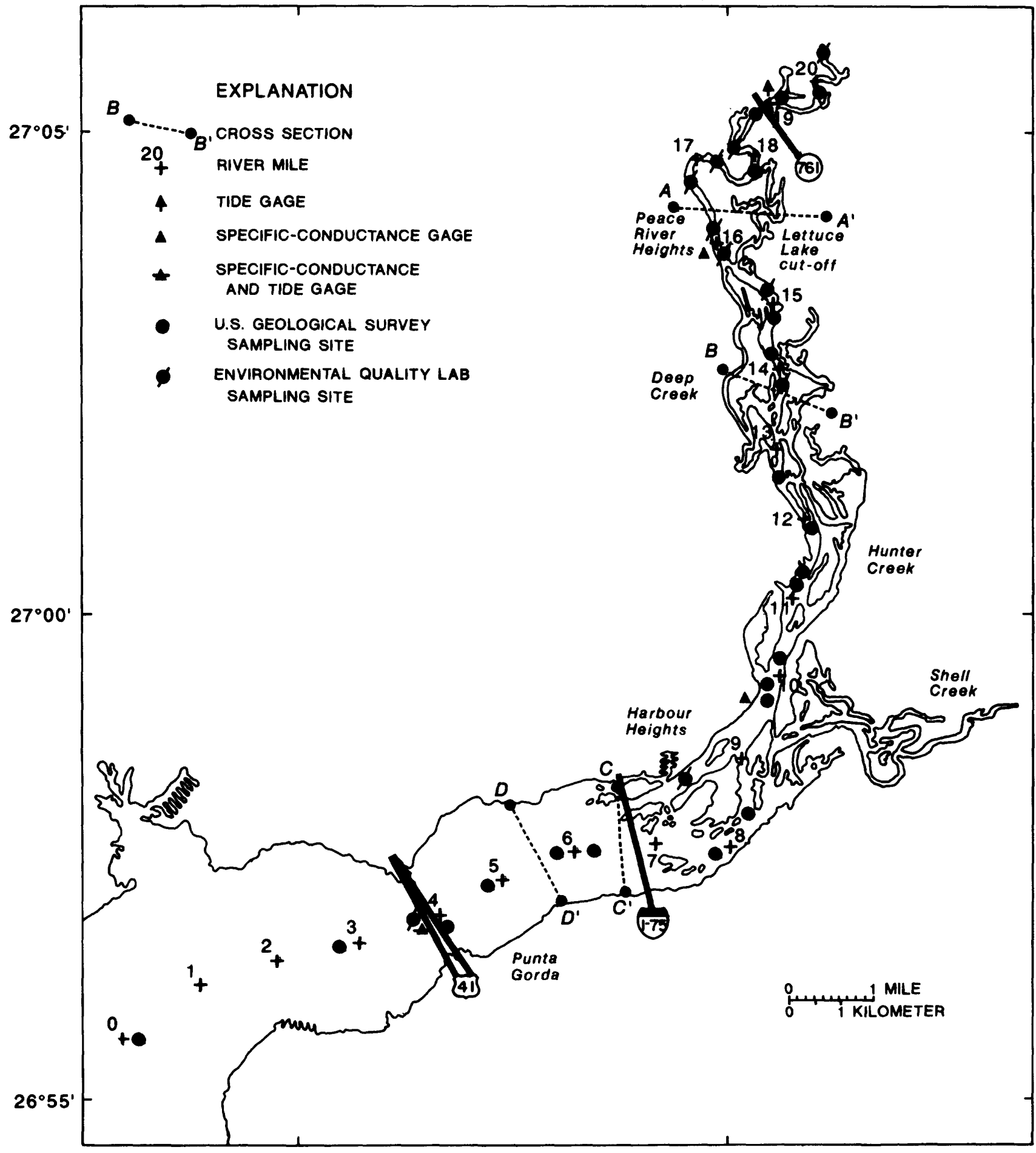

Figure 2.--Tidal Peace River, location of the tide and specific-conductance gages, and field measurement sites. 


\section{Freshwater Replacement Time}

Freshwater replacement time (FRT) was estimated for days that salinity field data were available. First, the volume of freshwater in the tidal river was determined from

$$
V_{f}=\left(1-\frac{S_{B}}{S_{O}}\right) V_{s}
$$

where

$V_{f}=$ volume of freshwater, in cubic feet;

$V_{s}=$ volume of the tidal Peace River at mean tide from State Road 761 to its mouth, in cubic feet;

$\mathrm{S}_{\mathrm{B}}=$ volume-weighted salinity of the tidal river, in parts per thousand; and

So $=$ salinity of harbor water entering the mouth of the river, in parts per thousand.

Second, the time taken for the total volume of the freshwater in the tidal river to be equaled or replaced by the freshwater inflow was calculated from

$$
T=\frac{V_{f}}{F W(86,400)}
$$

where

$\mathrm{T}=$ the time for the total volume of freshwater to be equaled or replaced by freshwater inflow, in days; and

FW = average daily freshwater inflow, in cubic feet per second.

The tidal river was divided into six sections, each of which included one or more salinity stations. The volume of each section and the total volume of the river reach was calculated for mean tide conditions.

The volume-weighted salinity $\left(\mathrm{S}_{\mathrm{B}}\right)$ was calculated as the depth-averaged salinity in a river section times the section volume divided by the total river volume. The salinity of the harbor water entering the river (So) was estimated using the near-bottom salinity value measured at or downstream of the seaward boundary. The volume of freshwater in the tidal river $\left(V_{f}\right)$ was estimated for days that salinity field data were available.

The freshwater inflow (FW) included both gaged and ungaged input. The gaged flow was the average discharge for the $\mathbf{3 0}$ days preceding the salinity sampling for the Peace River at Arcadia, Joshua Creek at Nocatee, Horse Creek near Arcadia, and Shell Creek near Punta Gorda. The ungaged flow was estimated to be 11 percent of the gaged flow based on drainage area ratios (Hammett, 1988). The rainfall contribution directly on the tidal river was considered negligible because evaporation from open water in the area approached rainfall amounts (Hughes, 1978). Ground-water inflows were not included because an undetermined amount of groundwater inflow was saline water.

\section{HYDRAULIC CHARACTERISTICS}

\section{Bathymetry and Flood-Plain Characteristics}

At normal stages, the channel of the Peace River upstream from Arcadia is well defined. Downstream from Arcadia, the river's flood plain widens, and below the mouth of Horse Creek, the river channel becomes more complex, with numerous off-channel storage areas and a network of channels that parallel and interconnect with the main river (fig. 2).

In the tidal river, the flood plain often exceeds a mile in width. Swamp hardwoods grow in the flood plain downstream to about river mile 15 , interspersed with small creeks and ponds (Environmental Quality Laboratory, Inc., 1982). Freshwater marshes and upland forest extend about a mile or so farther downstream where they merge with salt marsh and intertidal flats. Mangrove swamps border the lower islands and shoreline between river miles 10 and 7. Much of the shoreline downstream of river mile 7 has been altered by development.

River-bed elevations along the thalweg, or deepest part of the river channel, are irregular (fig. 3). Near the river mouth, the bed is about 10 feet below sea level. The bed becomes shallower several miles upstream and then becomes increasingly irregular, varying from about 5 to 20 feet below sea level along the remaining tidal reach (fig. 3). 


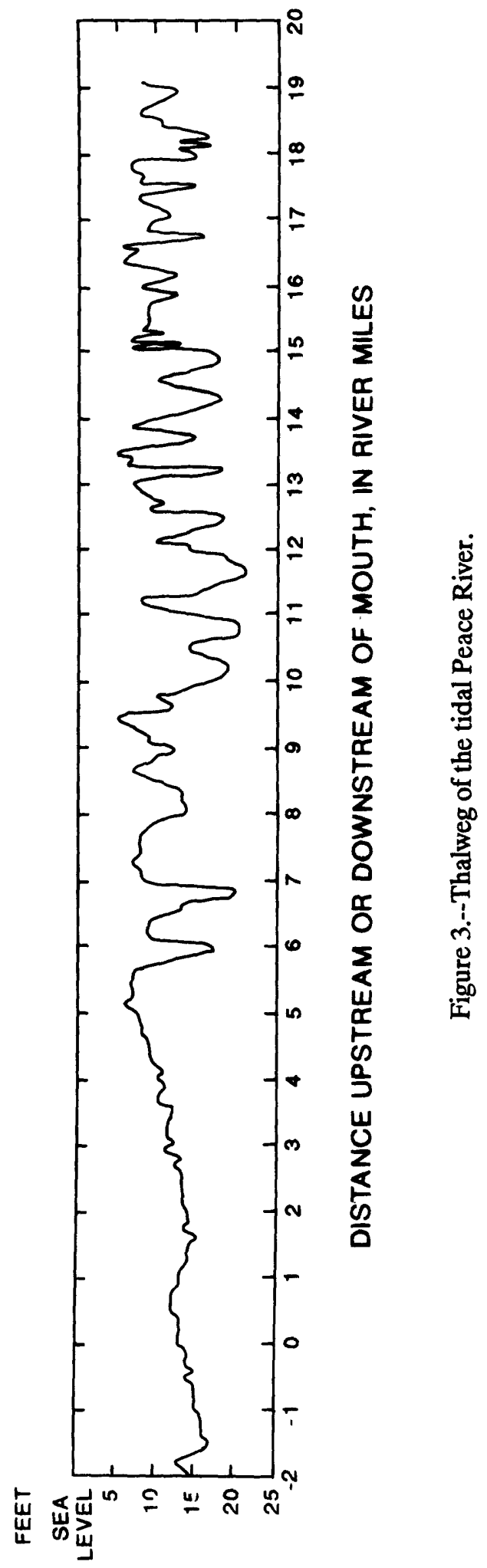

Figure 4 shows the land-surface elevations for selected cross sections in the tidal river. The locations of these cross sections are shown in figure 2. Several channels are evident in cross sections A$\mathrm{A}^{\prime}, \mathrm{B}-\mathrm{B}^{\prime}$, and C-C'. Some secondary channels (such as Lettuce Lake Cutoff, Deep Creek, and Hunter Creek) are distributaries of the main channel. This water is discharged back into the main channel several miles downstream on an ebbtide or several miles upstream on a floodtide.

\section{Tributary and Ground-Water Inflows}

Freshwater enters the tidal Peace River by tributary inflow, direct land runoff, and subsurface flow from the ground-water system. Freshwater inflow is seasonal; most occurs during the wet season, June through September. Major streams that discharge into the lower river are Joshua Creek, Horse Creek, and Shell Creek (fig. 1). These three tributaries and the main stem of the river at Arcadia are gaged and constitute the measured freshwater inflow to the tidal river. The sum of discharge from the Peace River at Arcadia, Joshua Creek at Nocatee, Horse Creek near Arcadia, and Shell Creek near Punta Gorda represents runoff from about $2,090 \mathrm{mi}^{2}$, or about 90 percent of the basin. Long-term average runoff for these sites ranges from 10.70 to 12.16 in/yr. Assuming runoff of $11.5 \mathrm{in} / \mathrm{yr}$ for the remainder of the $2,350-\mathrm{mi}^{2}$ basin, long-term average annual discharge to Charlotte Harbor would be $1,960 \mathrm{ft}^{3} / \mathrm{s}$.

Discharge hydrographs for the four gaging stations tributary to the tidal Peace River are shown in figure 5 for the period June 1982 through May 1986. This period includes dates of all salinity and discharge determinations shown and discussed in this report. Figure 6 shows the duration of combined daily mean discharge for the 1983-85 climatic years (May 1982 through April 1985), the period when salinity data were collected. Also shown in figure 6 are daily mean discharge durations for the 1966-85 climatic years (May 1965 through April 1985), the period of coincident record at the four gaging stations. The two curves indicate that inflow to the tidal river during the period of salinity monitoring was slightly greater than inflow during the $1966-85$ climatic years. 


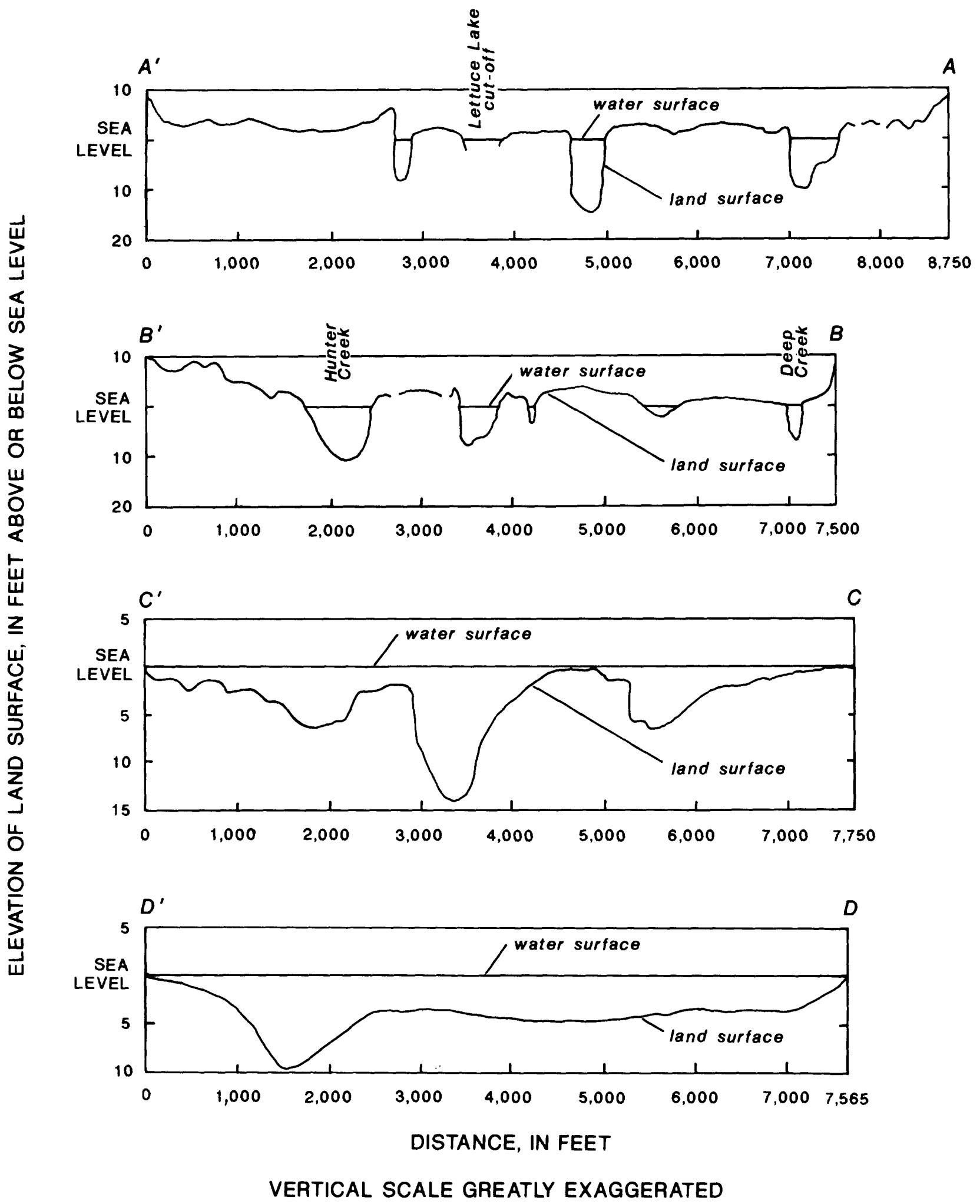

Figure 4.--Selected cross sections of the tidal Peace River. 

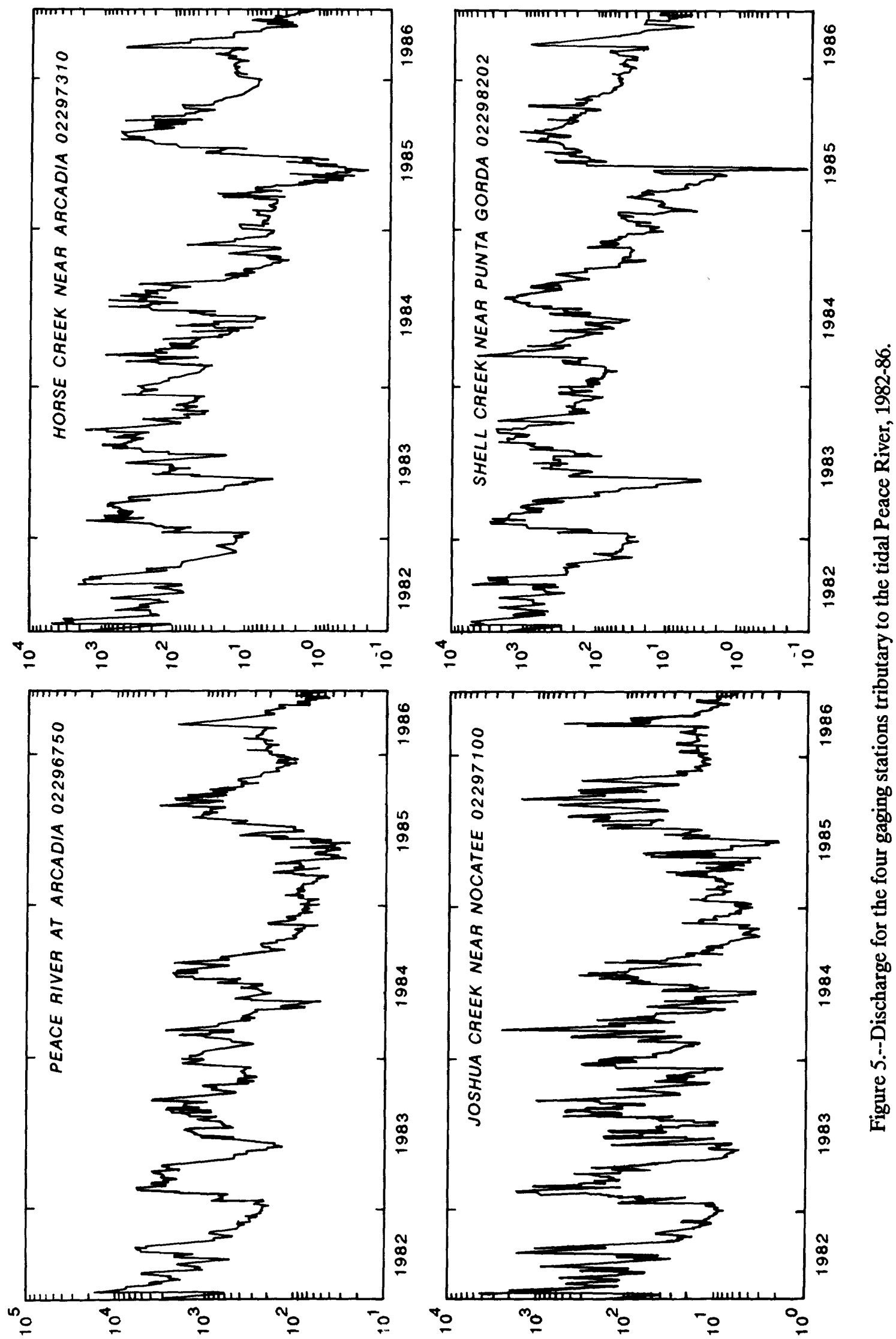

aNOO $\exists S$ \& 


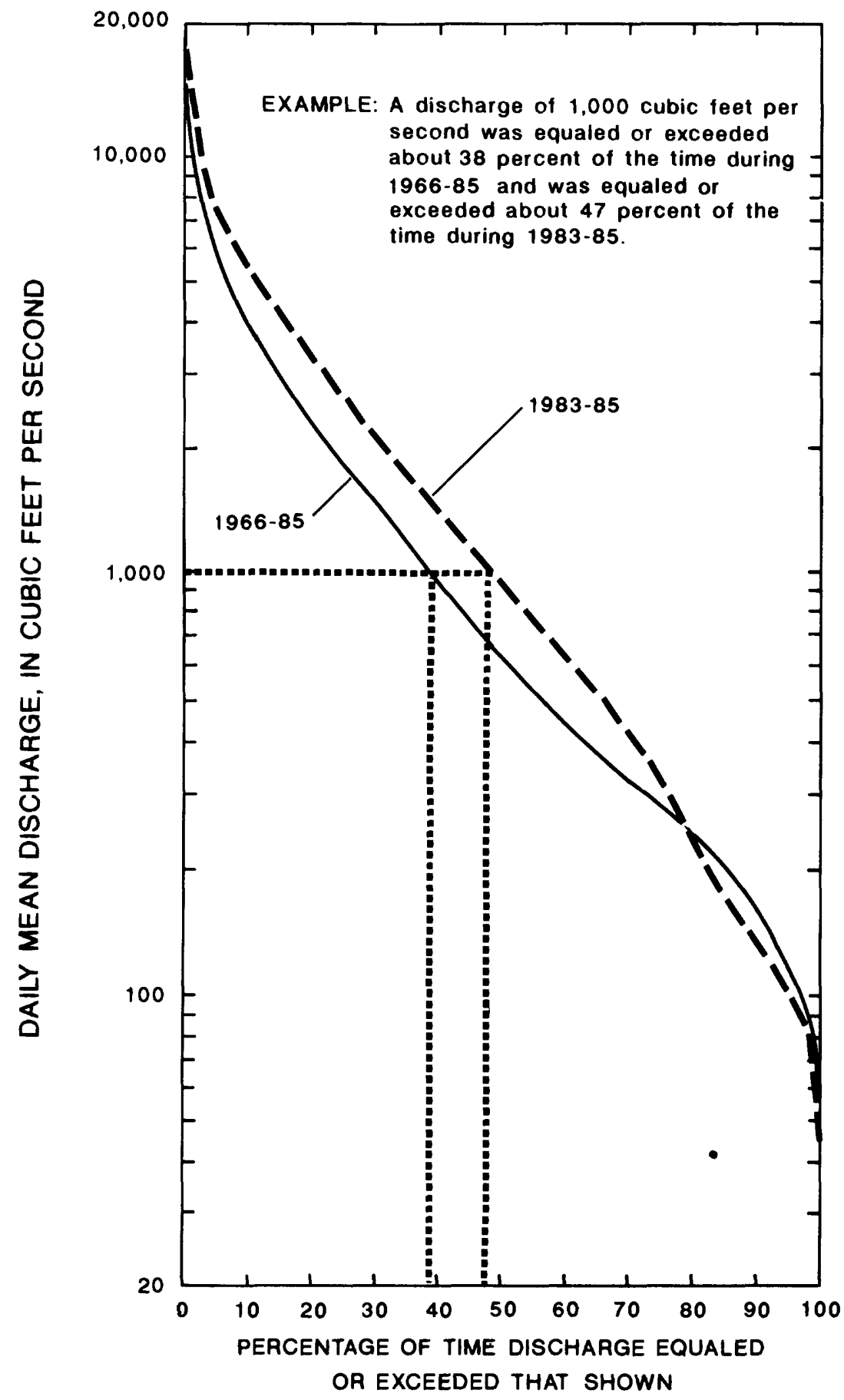

Figure 6.--Flow-duration curves for inflow to the tidal Peace River for climatic years 1966-85 and 1983-85 (May 1 through April 30). 


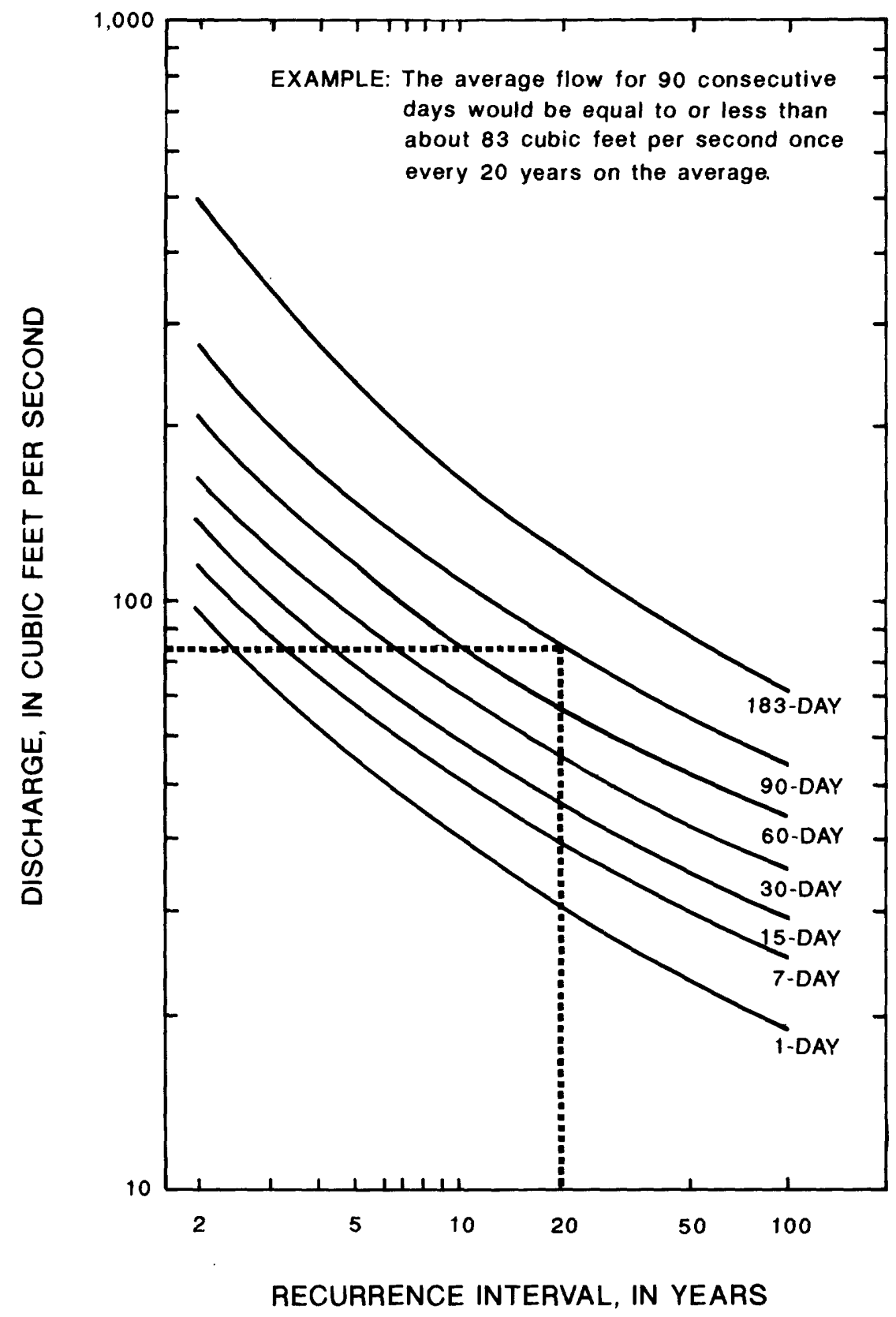

Figure 7.--Magnitude and frequency of annual low flow into the tidal Peace River.

Average flow from the four sites was $1,480 \mathrm{ft}^{3} / \mathrm{s}$ during 1965-85 and 1,680 $\mathrm{ft}^{3} / \mathrm{s}$ during 1983-85.

The low-flow characteristics of combined inflow to the tidal Peace River for 1966-85 are shown in figure 7 . The curves indicate the recurrence interval for given periods of low flows, ranging from 1 to 183 days, with recurrence intervals from 2 to 100 years. The example indicates the "90-day, 20-year low-flow discharge" would be about $83 \mathrm{ft}^{3} / \mathrm{s}$. These low-flow frequency curves are used later in this report to estimate the effects of decreased discharge on the upstream movement of saline waters from Charlotte Harbor. 
Inflow of ground water from the underlying aquifer system may augment flow to the Peace River (Wilson, 1977). The Upper Floridan aquifer has a potentiometric surface that ranges from about 50 feet above sea level at the upper end of the tidal reach to about 40 feet above sea level near the river mouth (Lewelling and Belles, 1986). A head differential of 30 to 40 feet offers the potential for a gain in river flow from the aquifer.

Evidence from ${ }^{226} \mathrm{Ra}$ and ${ }^{222} \mathrm{Rn}$ activity in river waters suggests that ground water may be a significant source of water to the tidal Peace River. The elevated activities of these isotopes in the tidal river and upper harbor appear to be primarily from a ground-water source (R.L. Miller, U.S. Geological Survey, written commun.,
1986). Miller estimated that ground-water inflow could contribute as much as 34 percent of the total Peace River basin inflow during periods of low flow.

\section{Tidal Stage}

Tides affecting the lower Peace River have an average range of about 2.2 feet and consist of both diurnal and semidiurnal components (figs. 8 and 9). Amplitude of the tide is slightly less near the mouth of the river than at the passes to the Gulf of Mexico, but increases about 0.1 foot at the gage at river mile 15.8. Gages upstream from this point show a continuing decrease in tidal amplitude until it approaches zero at about river mile 26. A storm surge or extremely high tide could affect river stages above this point.

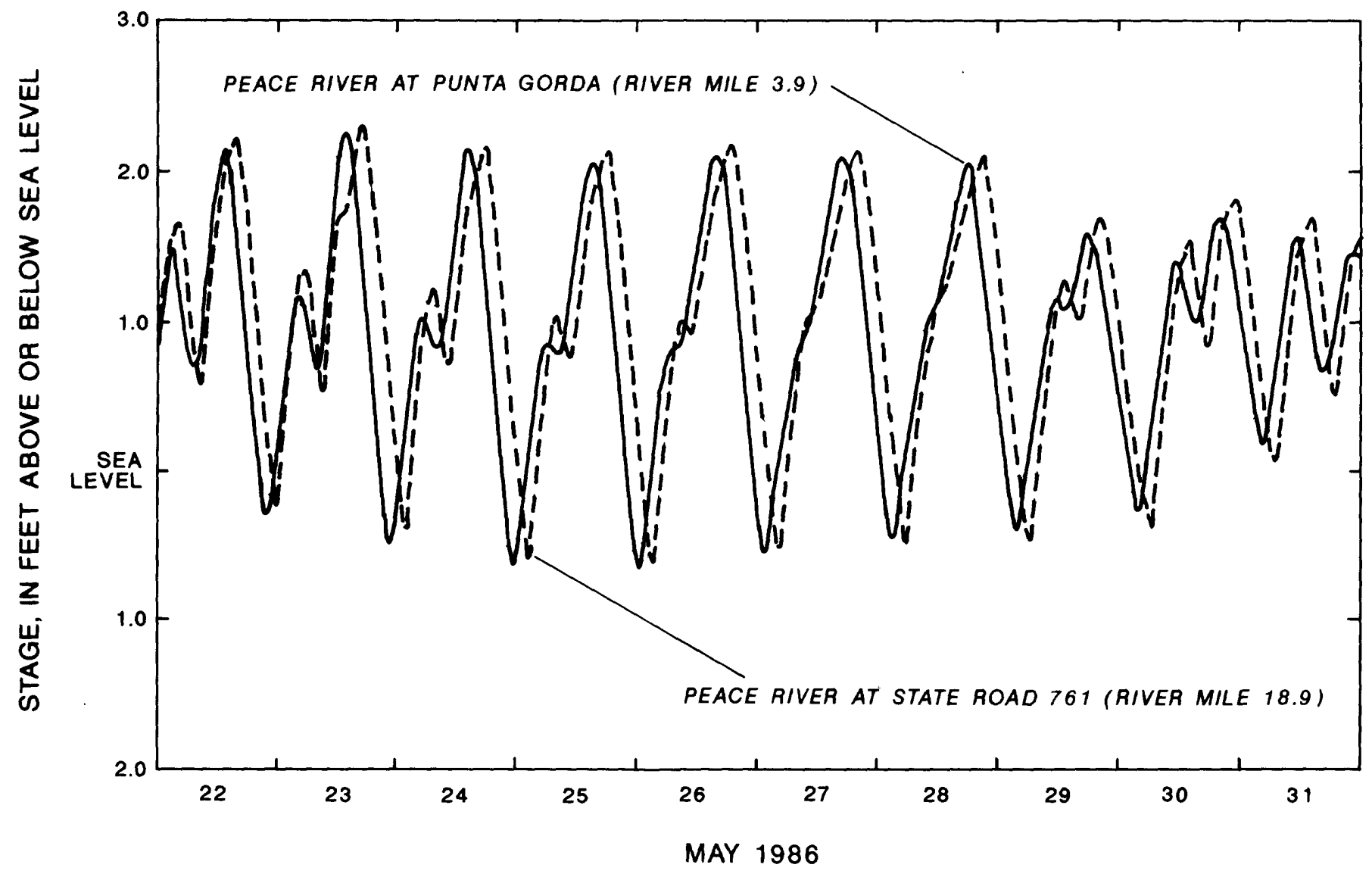

Figure 8.--Stages in the Peace River during low flow, May 22-31, 1986. 


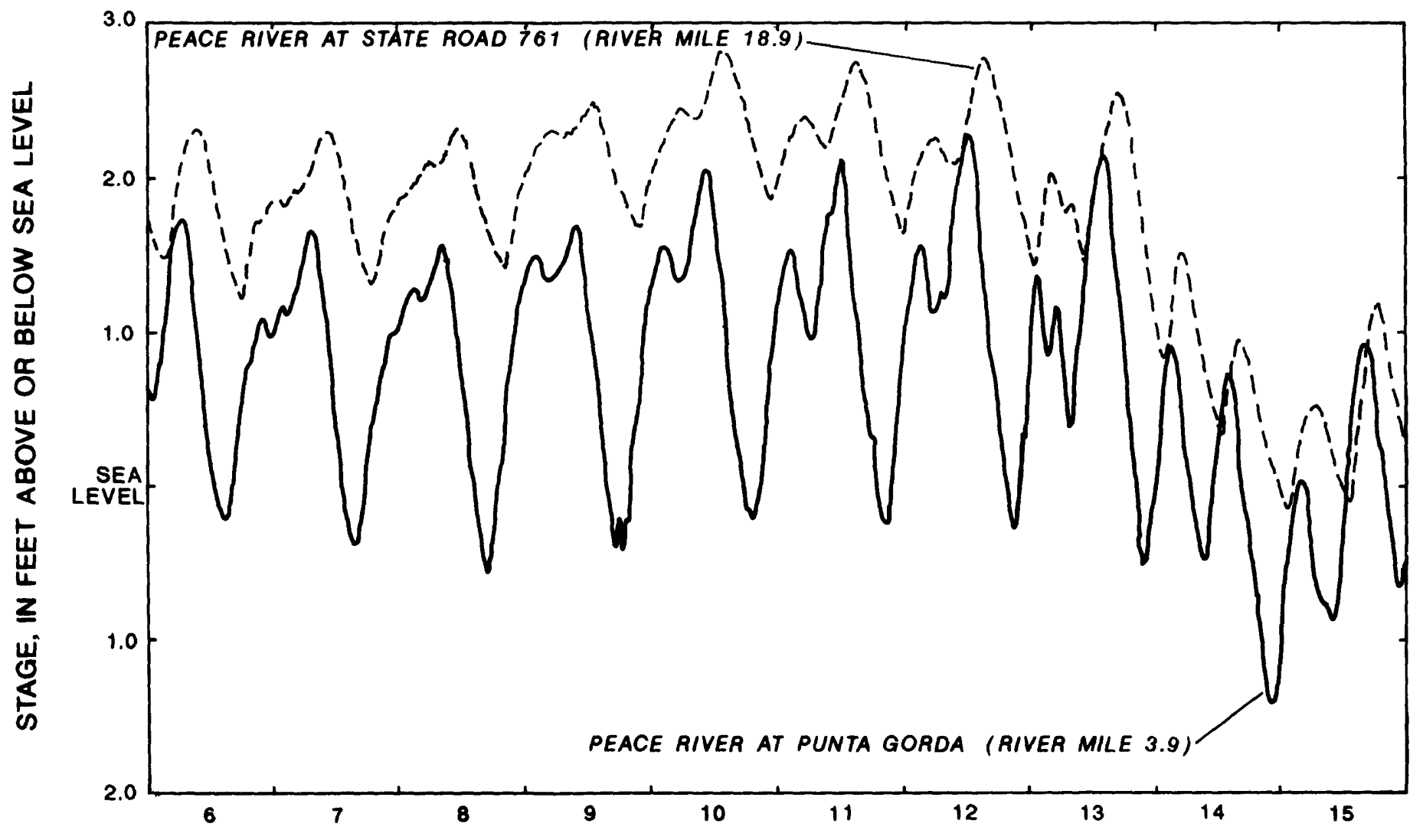

SEPTEMBER 1985

Figure 9.--Stages in the Peace River during high flow, September 6-15, 1985.

Increased river flow tends to decrease tidal ranges in the upper reaches of the tidal river (fig. 9). The increased stage, volume, and momentum of river flow tends to dampen the effects of tidal fluctuation. The period of the investigation had insufficient periods of high discharge to fully quantify the effects of inflow quantity on tidal stages. Analyses of flow during August and September 1985 indicated that tidal range at State Road 761, compared with the gage at river mile 3.9, decreases when gaged inflow from above State Road 761 exceeds about 1,500 $\mathrm{ft}^{3} / \mathrm{s}$. Tidal range at this station decreased by more than 50 percent when gaged river inflow increased beyond $4,000 \mathrm{ft}^{3} / \mathrm{s}$.

During periods of low flow, tidal peaks and troughs proceed upstream from the gage at Punta
Gorda to State Road 761 at an average speed of about $8.2 \mathrm{mi} / \mathrm{h}$. The average delay in tidal extremes between these two gages is 1 hour and 50 minutes for low-flow periods. During August and September 1985 , when monthly gaged river flow averaged 1,330 and $2,270 \mathrm{ft}^{3} / \mathrm{s}$, respectively, tidal peaks took an average of 2.5 hours to move the 15.0-mile distance, whereas tidal troughs took about 3 hours.

Patterns of tidal stage also are affected by storms and wind. Figure 10 shows the effects of Hurricane Elena on tidal stage in the Peace River at Punta Gorda. The hurricane passed west of the gulf coast moving northward into the central Gulf of Mexico on August 29-30, 1985. Winds on August 31 in Fort Myers averaged 14.6 knots from the south and gusted to 35 knots. Peak tidal stage 


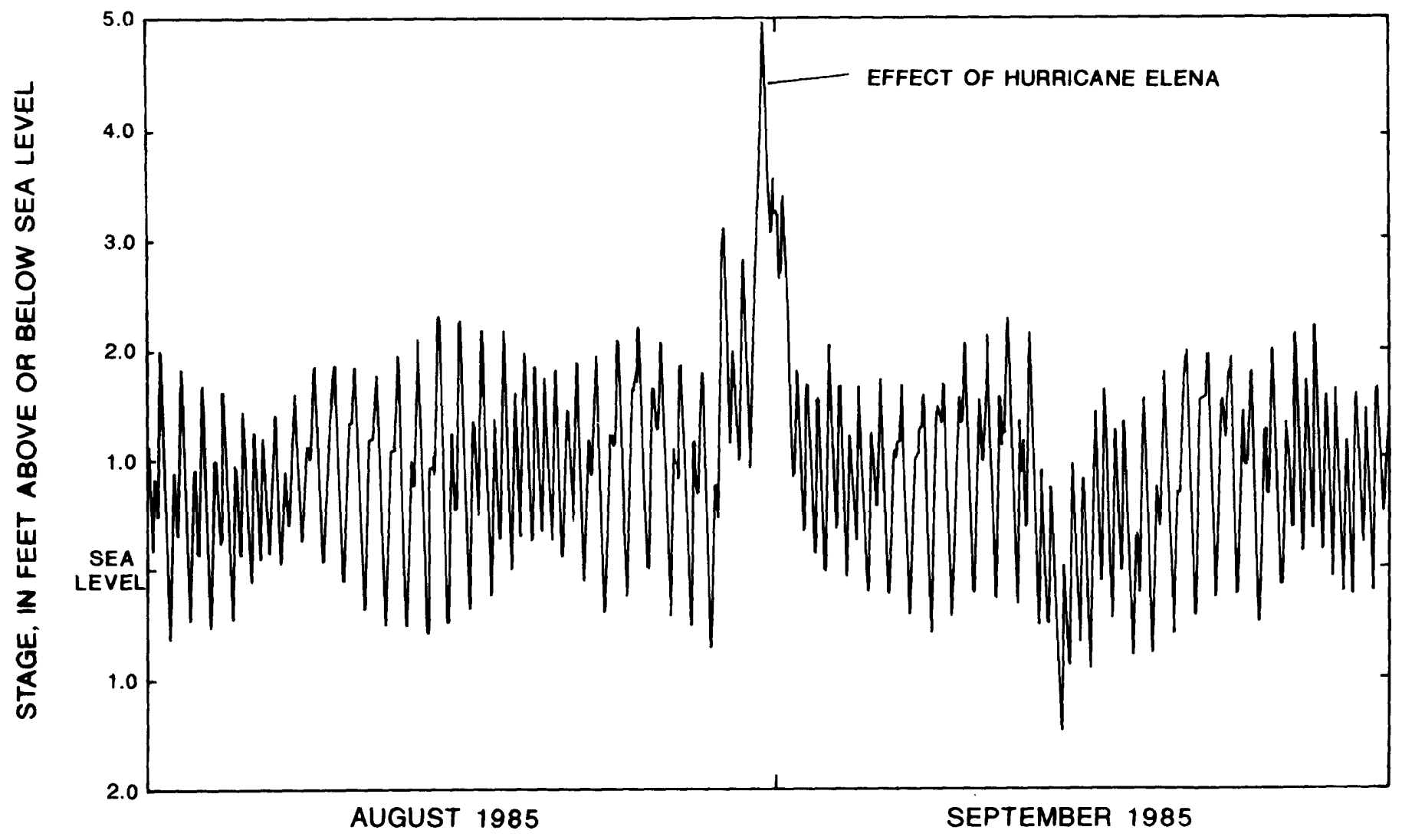

Figure 10.--Stage, Peace River at Punta Gorda, August and September 1985.

increased by about 3 feet during the storm surge. Tidal stage returned to normal in early September, but was depressed in mid-September (fig. 10) by strong northeasterly winds, which averaged 13 to 14 knots at Fort Myers.

\section{Tidal Velocity and Discharge}

Tidal stages, range of stages, and type of tide have pronounced effects on velocity and discharge in the tidal Peace River. Reversals in flow occur with each tide cycle at the mouth of the river. The extent to which flow reversals will move upstream is dependent both on tides and on the quantity of freshwater entering the system. Waters in the reach are mixed, routed through the several branches, and are stored both in the river channel and in the tidal flats and marshes.
Point velocities recorded at State Road 761 for the month of March 1986 are shown in figure 11. The lower half of the illustration compares daily mean discharge from the three upstream gaging stations and net daily flow computed from the point velocities. Point velocities for the first 2 weeks are typical of low flow, with flow reversals occurring each tidal cycle. Reversals ceased as inflow increased above $1,000 \mathrm{ft}^{3} / \mathrm{s}$ on March 16 , and discharge remained positive as long as inflow was above this threshold. Net daily discharge at State Road 761 (lower fig. 11) fluctuates above and below the gaged inflow during low flow but lags behind and peaks lower than the gaged inflow during higher flows. Receding from the peak, net daily discharge at State Road 761 is greater than the gaged inflow. This results from a combination 

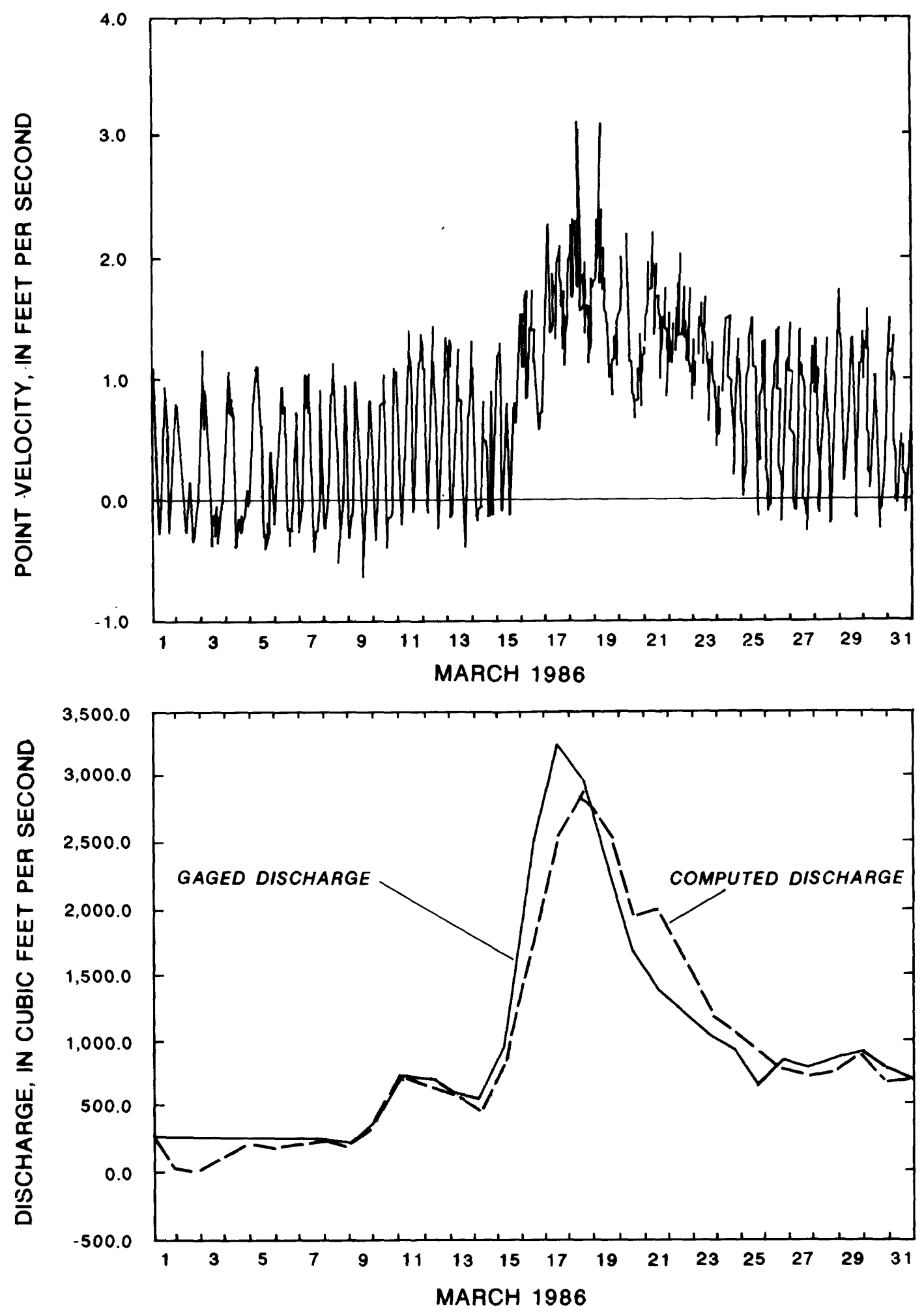

Figure 11.--Point velocities at State Road 761, gaged daily mean inflow above State Road 761, and daily mean discharge at State Road 761. 


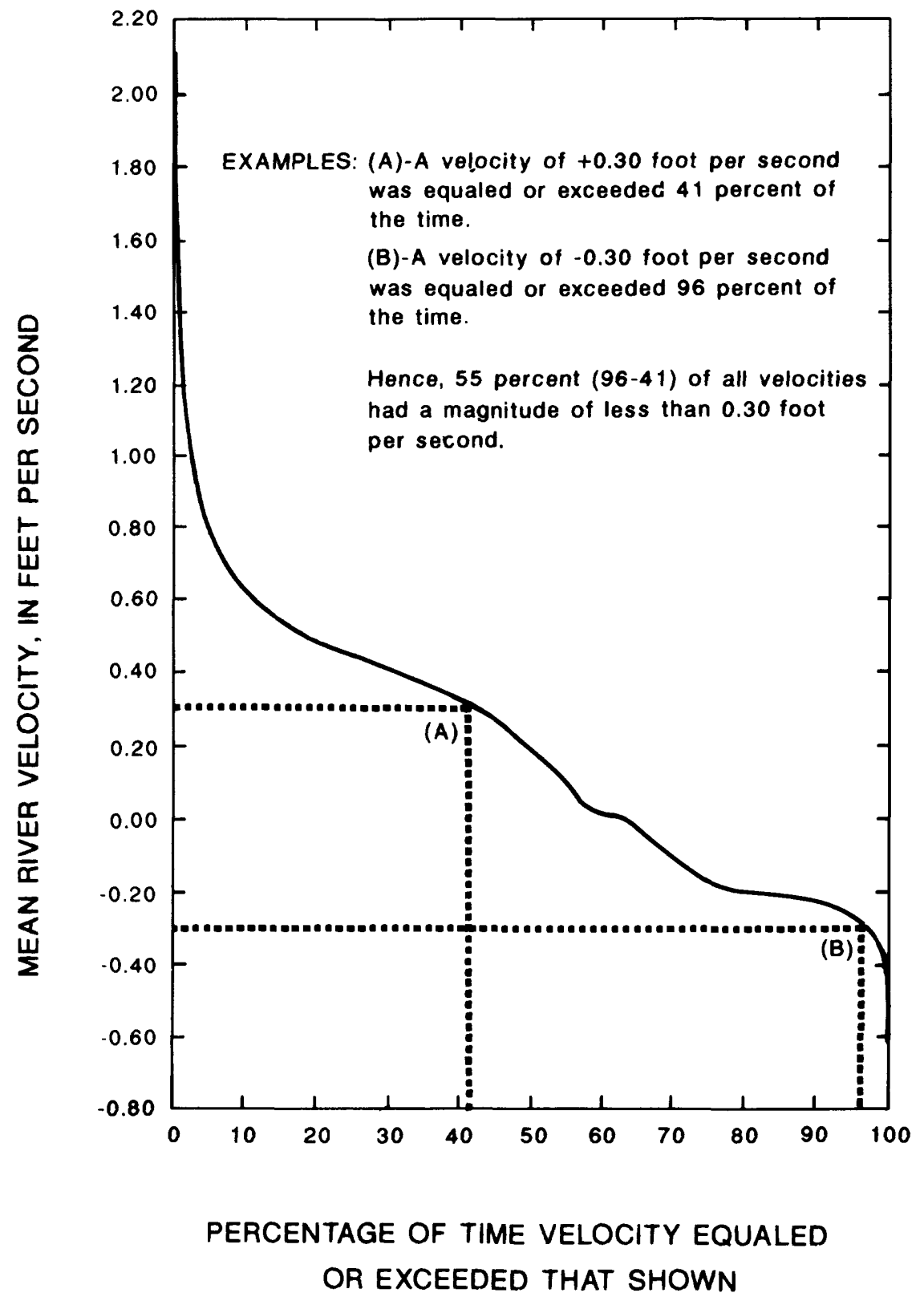

Figure 12.--Duration of instantaneous mean river velocities at river mile 18.9, State Road 761, for December 1985 through May 1986.

of travel time and storage in the hydraulic system between the upstream gages and State Road 761.

Figure 12 shows the duration of mean crosssectional velocities for both upstream and downstream flow for the period December 1985 through May 1986. Mean cross-sectional velocities were computed from a mean-point velocity rating developed relating recorded point velocities to mean velocities of individual discharge measurements. Gaged inflow upstream of 
State Road 761 for the 6-month period ranged from 44 to $3,100 \mathrm{ft}^{3} / \mathrm{s}$ and averaged about 320 $\mathrm{ft}^{3} / \mathrm{s}$. Although the gage location was selected to provide maximum velocities in the cross-section, the low velocities typical throughout the tidal reach are indicated by the duration curve. As the examples indicate, velocities greater than $0.3 \mathrm{ft} / \mathrm{s}$ occurred only 41 percent of the time at State Road 761. Velocities measured at river mile 11.5 were only slightly higher than at State Road 761. These low velocities compound the problems associated with defining unsteady flow in the tidal reach.

A summary of discharge determinations in the tidal Peace River is tabulated in table 1. Four suites of discharge measurements at State Road 761 are described in the table and shown graphically in figures 13 and 14. Discharge for the first three tidal-cycle measurements has been interpolated from the point-velocity data collected every 15 minutes with Price current meters. The discharge for December 1985, the lower half of figure 14, shows discharge computed using velocities recorded every 5 minutes by the electromagnetic meter installed at the State Road 761 bridge. The erratic pattern of the computed discharge for December 1985 indicates the variability of velocities in the river.

Discharge in July 1984 was measured in both the main river channel at river mile 11.5 and in Hunter Creek adjacent to river mile 11.5 (fig. 15). The sum of these two parallel branches represents the total flow in this reach of the river. Hunter Creek conveyed about 27 percent of total maximum flow during this measurement period. Discharge extremes induced by tidal fluctuations were approximately seven times the total inflow to the tidal reach of the river at river mile $\mathbf{1 1 . 5}$ and approximately five times the discharge occurring at State Road 761 at river mile 18.9. Reverse flow during floodtide was only slightly less than downstream discharge during ebbtide, indicating that tidal influences generate significant movement of water independent of inflow in this part of the tidal river.

\section{SALINITY CHARACTERISTICS}

\section{Salinity Distribution}

Salinity distributions along a 20-mile reach of the tidal Peace River for $\mathbf{1 5}$ days during the study are arranged in order of increasing freshwater

Table 1.--Ranges in velocity and discharge measured at river miles 18.9 and 11.5 in the tidal Peace River

[ft ${ }^{3} / \mathrm{s}$, cubic feet per second; $\mathrm{ft} / \mathrm{s}$, feet per second]

\begin{tabular}{|c|c|c|c|c|c|c|}
\hline & \multicolumn{4}{|c|}{$\begin{array}{l}\text { River mile } 18.9 \\
\text { (State Road 761) }\end{array}$} & \multicolumn{2}{|c|}{$\begin{array}{l}\text { River mile } 11.5 \\
\text { July } 12-13,1984\end{array}$} \\
\hline & $\begin{array}{c}\text { July 10-11, } \\
1984\end{array}$ & $\begin{array}{c}\text { February 1, } \\
1985\end{array}$ & $\begin{array}{c}\text { May 7, } \\
1985\end{array}$ & $\begin{array}{c}\text { December 11-12, } \\
1985\end{array}$ & $\begin{array}{c}\text { Main } \\
\text { channel }\end{array}$ & $\begin{array}{l}\text { Hunter } \\
\text { Creek }\end{array}$ \\
\hline $\begin{array}{c}\text { Gaged freshwater } \\
\text { inflow, } \mathrm{ft}^{3} / \mathrm{s}\end{array}$ & 913 & 140 & 57 & 135 & & \\
\hline $\begin{array}{c}\text { Number of discharge } \\
\text { measurements }\end{array}$ & 10 & 7 & 4 & 7 & 8 & 8 \\
\hline $\begin{array}{r}\text { Measured mean } \\
\text { velocity, } \mathrm{ft} / \mathrm{s}\end{array}$ & $\begin{array}{c}0.20 \text { to } \\
0.920\end{array}$ & -0.45 to & -0.44 to & -0.39 to & -1.09 to & -0.82 to \\
\hline 0.520 .51 & 0.67 & 1.38 & 0.98 & & & \\
\hline $\begin{array}{l}\text { Measured discharge, } \\
\mathrm{ft}^{3} / \mathrm{s}\end{array}$ & $\begin{array}{l}466 \text { to } \\
2,080\end{array}$ & $\begin{array}{c}-1,010 \text { to } \\
1,160\end{array}$ & $\begin{array}{c}-826 \text { to } \\
841\end{array}$ & $\begin{array}{c}-1,380 \text { to } \\
1,580\end{array}$ & $\begin{array}{c}-6,900 \text { to } \\
7,960\end{array}$ & $\begin{array}{c}-2,430 \text { to } \\
2,670\end{array}$ \\
\hline
\end{tabular}




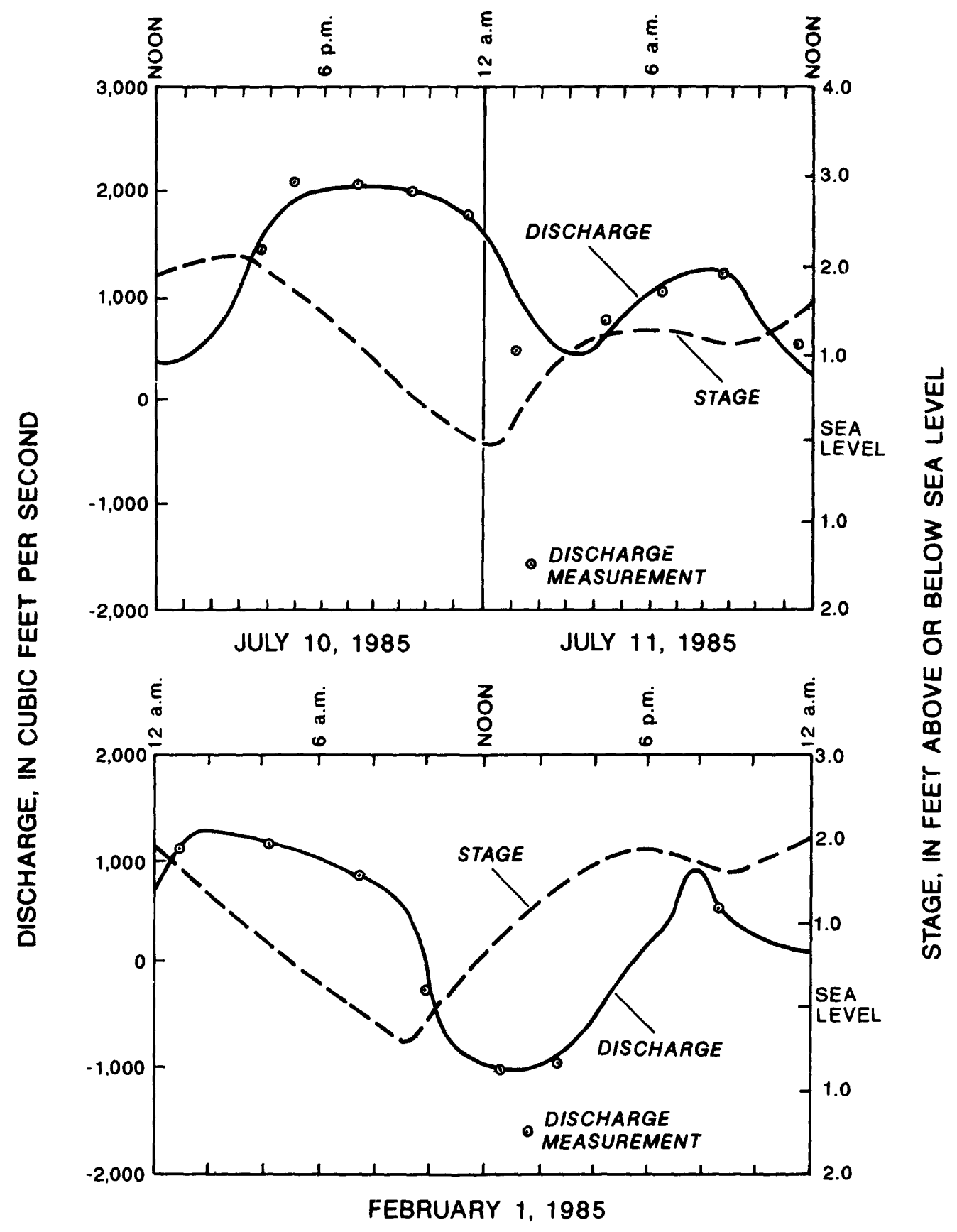

Figure 13.--Stage and discharge at State Road 761 for July 10-11, 1984, and February 1, 1985. 


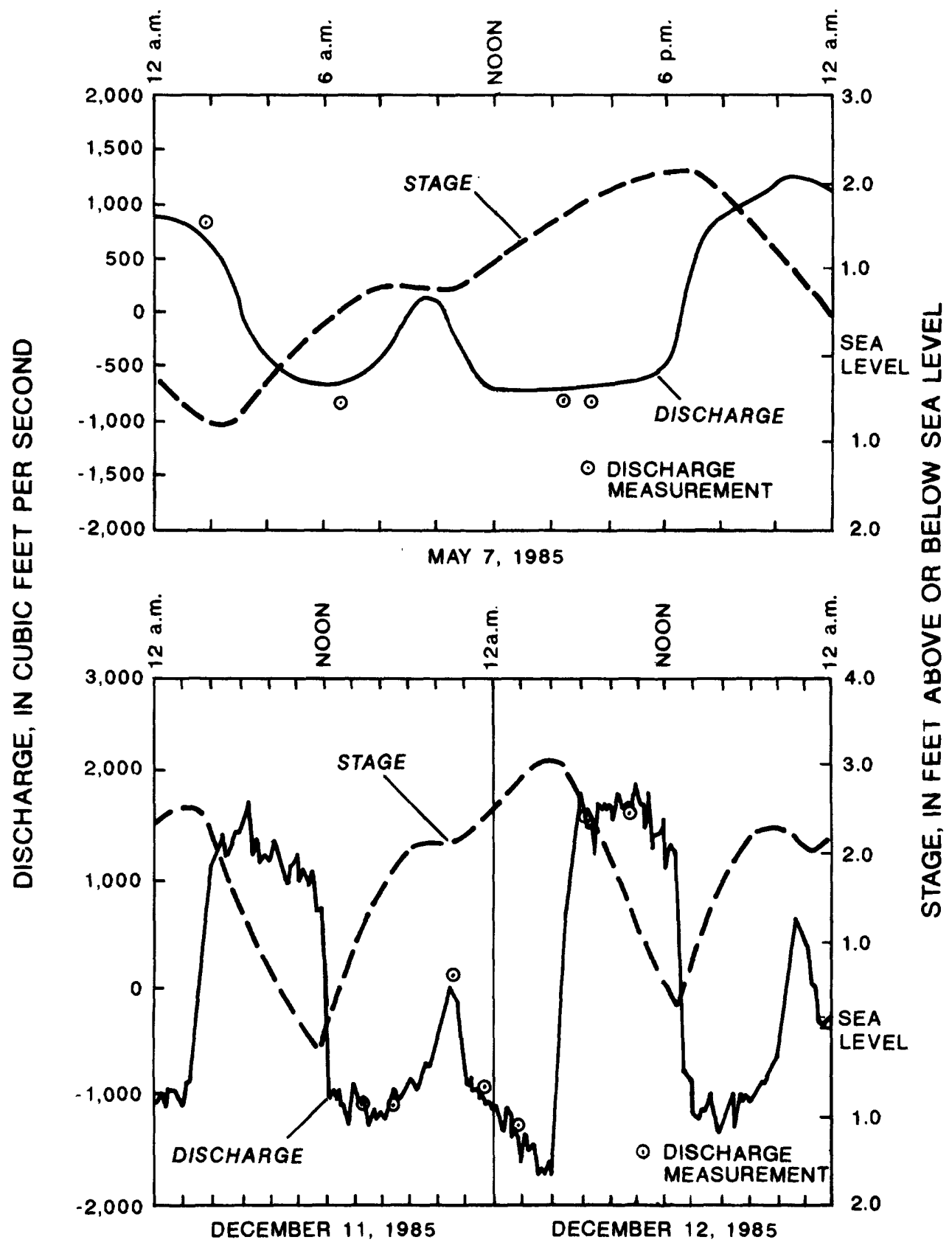

Figure 14.--Stage and discharge at State Road 761 for May 7 and December 11-12, 1985. 


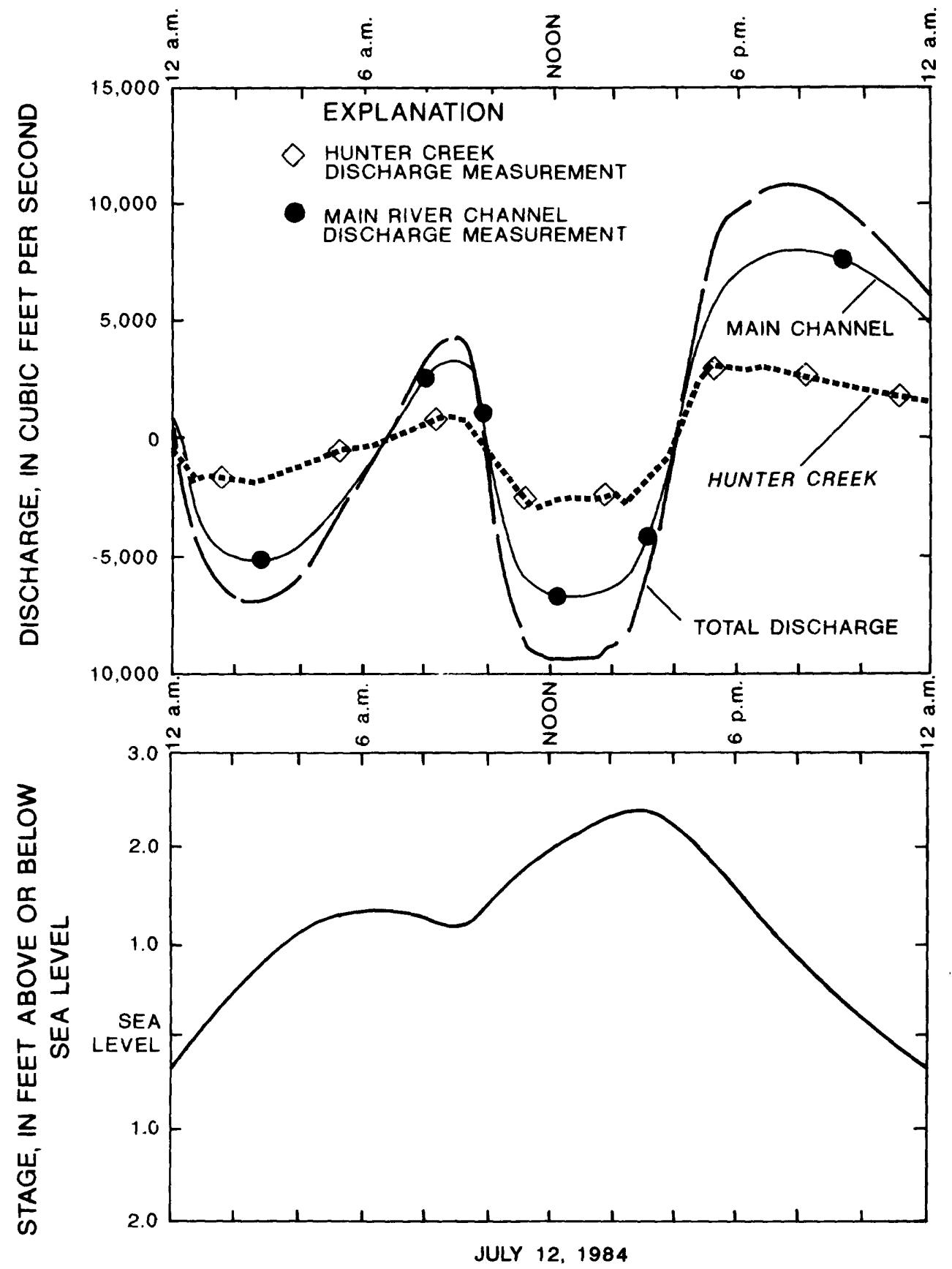

Figure 15.--Stage and discharge in main channel at river mile 11.5 and in Hunter Creek on July 12, 1985. 
inflow at Arcadia in figure 16. Several characteristics become apparent in the figure. First, salinity distribution is related not only to the shortterm discharge at Arcadia but also to seasonal or long-term (months) freshwater runoff and salinity in the harbor. For example, plots 1, 2, and 5 are quite similar and represent high-salinity conditions during a period of unusually low freshwater inflow from October 1984 through most of July 1985 (fig. 5). Salinity patterns were a result more of high salinity in Charlotte Harbor rather than daily discharges at Arcadia. Second, vertical salinity stratification (as indicated by differences between near-surface and near-bottom salinity) was minimal at low freshwater inflows (plots 1 through 9), but became pronounced as inflow approached and exceeded $500 \mathrm{ft}^{3} / \mathrm{s}$ at Arcadia (plots 10 through 15). Third, near-bottom salinity near the river mouth (below river mile 4) was not greatly affected by freshwater inflow and remained at about $20 \mathrm{ppt}$ or higher even during flood conditions on June 25, 1982 (plot 15). Fourth, vertical and longitudinal salinity patterns are affected by the two bridges that span the lower river. Some of the plots in figure 16 show breaks or discontinuities in salinity distribution at river miles 4 and 6.5 where bridges for U.S. Highway 41 and Interstate Highway 75 , respectively, span the river. The bridges may affect circulation and mixing by constricting channel width and increasing turbulence around pilings. The most dramatic bridge effect on salinity is seen on June 25,1982 , during a 10-year flood in the Peace River at Arcadia (plot 15). Highly stratified conditions occurred downstream of mile 4 (U.S. Highway 41), whereas upstream water was essentially fresh at all depths.

\section{Salinity Fluctuations}

The specific-conductance gages provided detailed information on short-term (daily) and long-term (April 1983 through December 1985) near-bottom salinity fluctuations at specific fixed sites in the tidal river. Average daily fluctuations of near-bottom salinities were caused by tides and ranged from 1.6 to $7.5 \mathrm{ppt}$ depending on location. Magnitude of daily fluctuations increased downstream from river mile 15.8 to 3.9 , as shown below:

\begin{tabular}{|c|c|c|c|}
\hline Gage & $\begin{array}{l}\text { River } \\
\text { mile }\end{array}$ & $\begin{array}{c}\text { Maximum daily } \\
\text { fluctuation, } \\
\text { April 1983- } \\
\text { December } 1985 \\
\text { (ppt) }\end{array}$ & $\begin{array}{c}\text { Average daily } \\
\text { fluctuation, } \\
\text { April 1983- } \\
\text { December 1985 } \\
\text { (ppt) }\end{array}$ \\
\hline Peace River Heights & 15.8 & 12.0 & 1.6 \\
\hline Harbour Heights & 9.7 & 15.1 & 4.9 \\
\hline Punta Gorda & 3.9 & 30.7 & 7.5 \\
\hline
\end{tabular}

Daily mean salinity at each gage is shown in figure 17. Although day-to-day salinity patterns are erratic, long-term salinity fluctuations caused by changes in freshwater runoff are apparent. Average near-bottom salinities were elevated at the gages during a prolonged drought, October 1984-July 1985, compared with the period of record, as shown below:

\begin{tabular}{lrcc}
\hline \multicolumn{1}{c}{ Gage } & $\begin{array}{c}\text { Average salinity, Average salinity, } \\
\text { River } \\
\text { mile }\end{array}$ & $\begin{array}{c}\text { April 1983- } \\
\text { December 1985 } \\
\text { (ppt) }\end{array}$ & $\begin{array}{c}\text { October 1984- } \\
\text { July 1985 } \\
\text { (ppt) }\end{array}$ \\
\hline Peace River Heights & 15.8 & 1.1 & 3.3 \\
Harbour Heights & 9.7 & 6.9 & 14.2 \\
Punta Gorda & 3.9 & 19.7 & 29.8 \\
\hline
\end{tabular}

Figure 18 compares near-surface and near-bottom salinity with tidal stage at the Punta Gorda gage during high flows in September 20-26, 1985. The combined daily mean discharge at Arcadia and the three downstream tributaries averaged $2,900 \mathrm{ft}^{3} / \mathrm{s}$ during this period. This flow was equaled or exceeded 22 percent of the time during the study (fig. 6). Fluctuations in near-surface salinity corresponded more or less directly with tide stage; the lowest salinity for the day occurred at or shortly after the lowest tide, and peak salinity occurred at high tide. Surface salinity peaks were not as well defined during low inflow conditions and tended to level off. Fluctuations in near-bottom salinity also corresponded with tidal stage, but the range of daily changes was usually less than surface changes. Lowest nearbottom daily salinity occurred just before the lowest tide. Sahinity increased with incoming tide but leveled off during high tide, regardless of freshwater inflow conditions. Continuous discharge interpolated from recorded point 

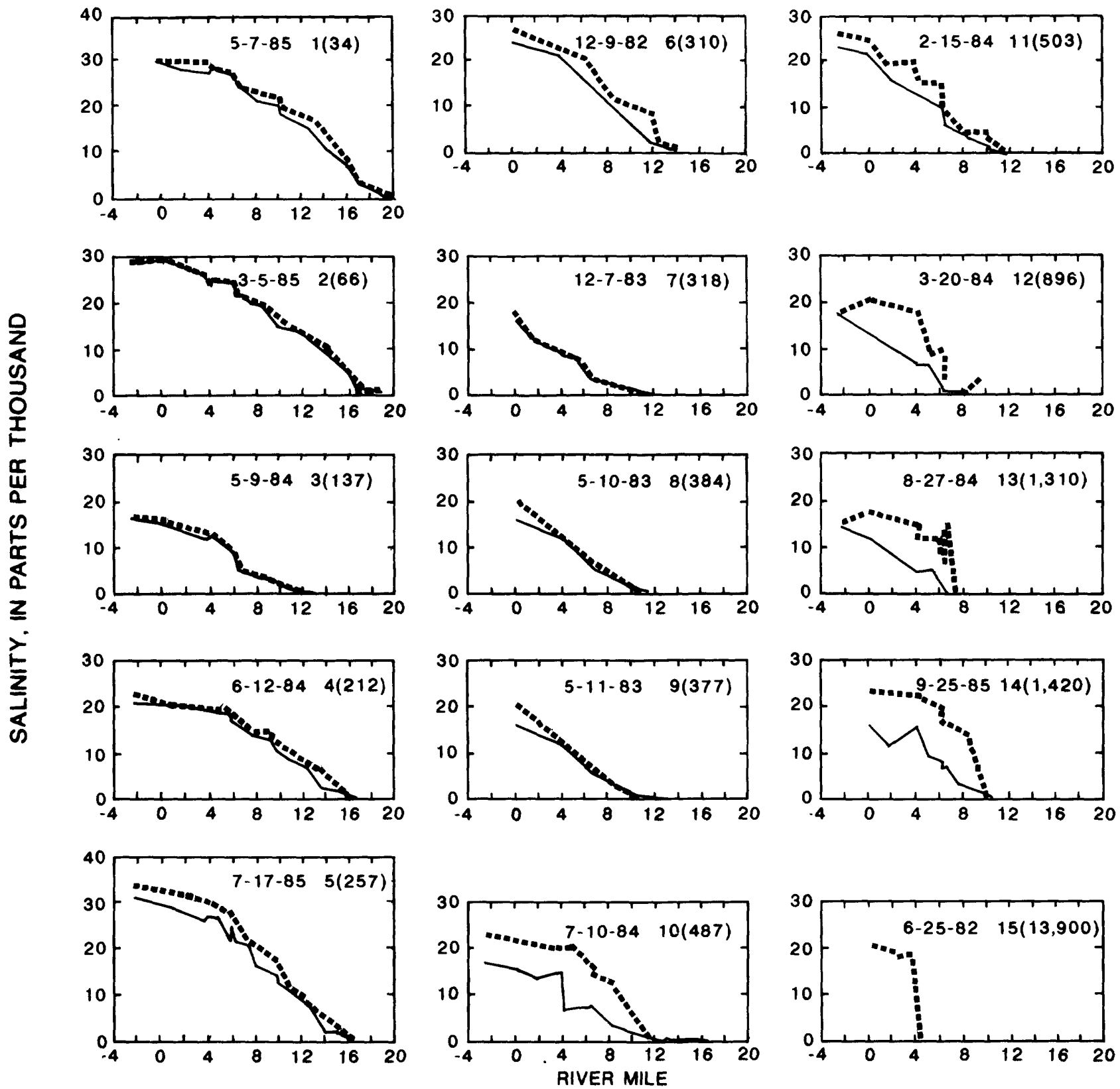

\section{EXPLANATION}

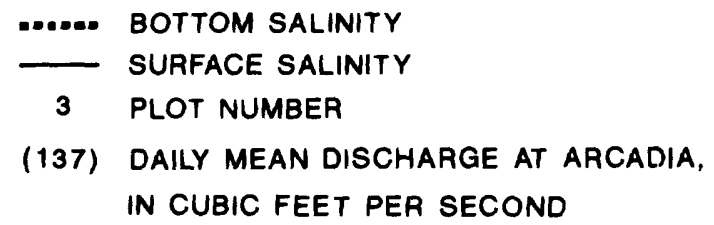

Figure 16.--Field measurements of near-surface and near-bottom salinity as a function of river mile.

(Plots are arranged in order of increasing daily mean discharge at the Peace River at Arcadia.) 

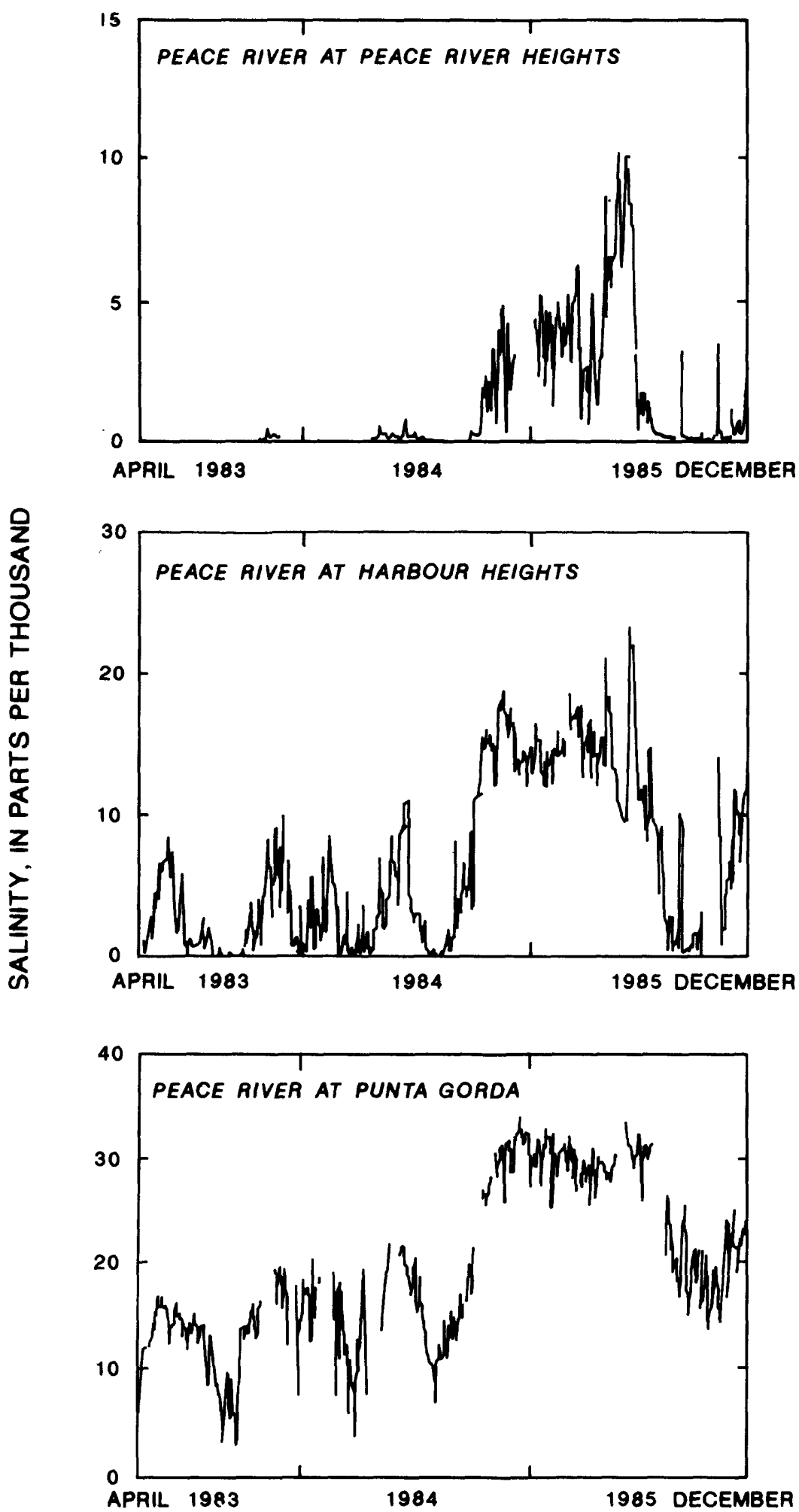

Figure 17.--Daily mean salinity at the river gage sites. 

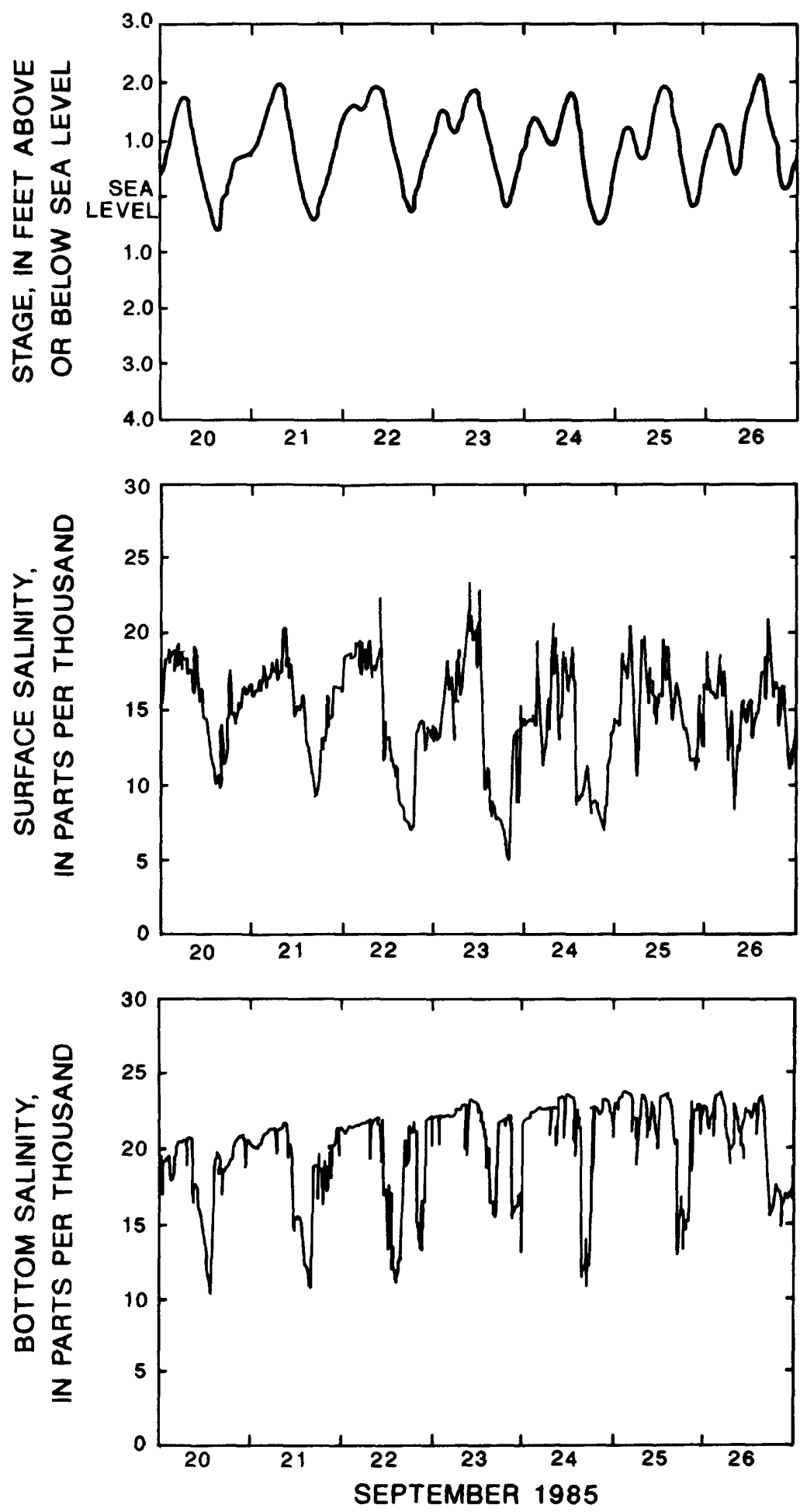

Figure 18.--Stage and near-surface and near-bottom salinity at Punta Gorda, September 20-26, 1985. 
velocities measured December 11-12, 1985, at State Road 761 indicates that discharge peaks also flatten out in relation to tide stage (fig. 14). These unsteady flow conditions are probably typical and contribute to the erratic salinity patterns observed in relation to tidal stage.

The magnitude of vertical salinity stratification varied during the tidal cycle. The largest difference between near-surface and near-bottom salinity occurred just after low tide and the smallest difference occurred at high tide (fig. 19). The brief periods of negative differences (surface salinity greater than bottom salinity) may be due to sampling error or to turbulent mixing at the bridge at the time the salinities were recorded.

Duration curves based on instantaneous (15minute interval) salinity readings at the three gages are shown in figure 20 . The median salinity at the gages ranged from $0.2 \mathrm{ppt}$ at Peace River Heights to $18.6 \mathrm{ppt}$ at Punta Gorda. Duration curves are based on values recorded April 1983 through December 1985.

\section{Salinity Location Regression Analyses}

The location of a given salinity within the river can be estimated by regressing salinity location versus freshwater inflow, tidal parameters, or daily mean conductance at a given gage site. Salinities of $0.5,1,5,10,15$, and $20 \mathrm{ppt}$ were chosen for the regression analyses. Because the Peace River is often vertically stratified, near-bottom and near-surface salinities were studied separately. For each set of high-tide field measurements, the location of each salinity was determined by linear interpolation between measurement sites and was expressed in river miles upstream from the mouth. This location represents the high-tide, stream-center location of the six salinities chosen for analyses.

Two approaches based on linear-regression techniques were used to predict the high-tide locations of the selected salinities:

1. Relation between location and daily mean conductance at the three gages, and

2. Relation between location and magnitude of freshwater inflow and tidal stage.

The advantage of the first approach is that the daily mean conductance at the recording gages integrates the complex interactions of tide, wind, harbor salinity, and freshwater inflows on salinity distribution in the tidal river; however, the operation of the gages would need to continue if the regressions were to be used for predictions. The disadvantage is that conductance gages are expensive and time consuming to operate. The advantage of the second approach is that the relative impacts freshwater inflow and tide have on salinity patterns can be evaluated; however, important determinants, such as wind and harbor salinity, are excluded from the analysis.

\section{Salinity Locations Estimated from Specific} Conductance at Fixed Gages

The results of the regressions of salinity location versus daily mean conductance at the gages are shown in table 2 . The dependent variable, salinity location, was entered as a river mile. For both near-surface and near-bottom salinities in the 0.5- to 10-ppt range, the daily mean conductance at Harbour Heights was the best independent variable for estimating high-tide salinity locations. The 15- and 20-ppt salinity locations were best predicted by the Punta Gorda gage. The Peace River Heights gage was too far upstream to correlate significantly with the salinities; the individual salinity locations were usually far downstream of the gage. Coefficients of determination $\left(R^{2}\right)$ ranged from 0.78 to 0.89 , and most root mean square errors (RMSE) were less than 1.5 miles. All regressions were significant at the 5-percent probability level.

Using the equations obtained in the regression analysis, the daily high-tide location for each salinity was computed for the period April 1983 to December 1985. A duration analysis of the estimated daily salinity locations was done for each near-surface and near-bottom salinity to show the percent of time each salinity was at or upstream of a particular location in the tidal river. Figure 21 shows examples of the duration curves.

The 50-percent frequency locations of the estimated daily high-tide salinities are shown in figure 22. These locations represent the median locations for the 0.5-, 1-, 5-, 10-, and 15-ppt salinities. The bottom salinity locations are between 0.1 and 1.0 mile upstream of the corresponding surface salinities (fig. 22), which 

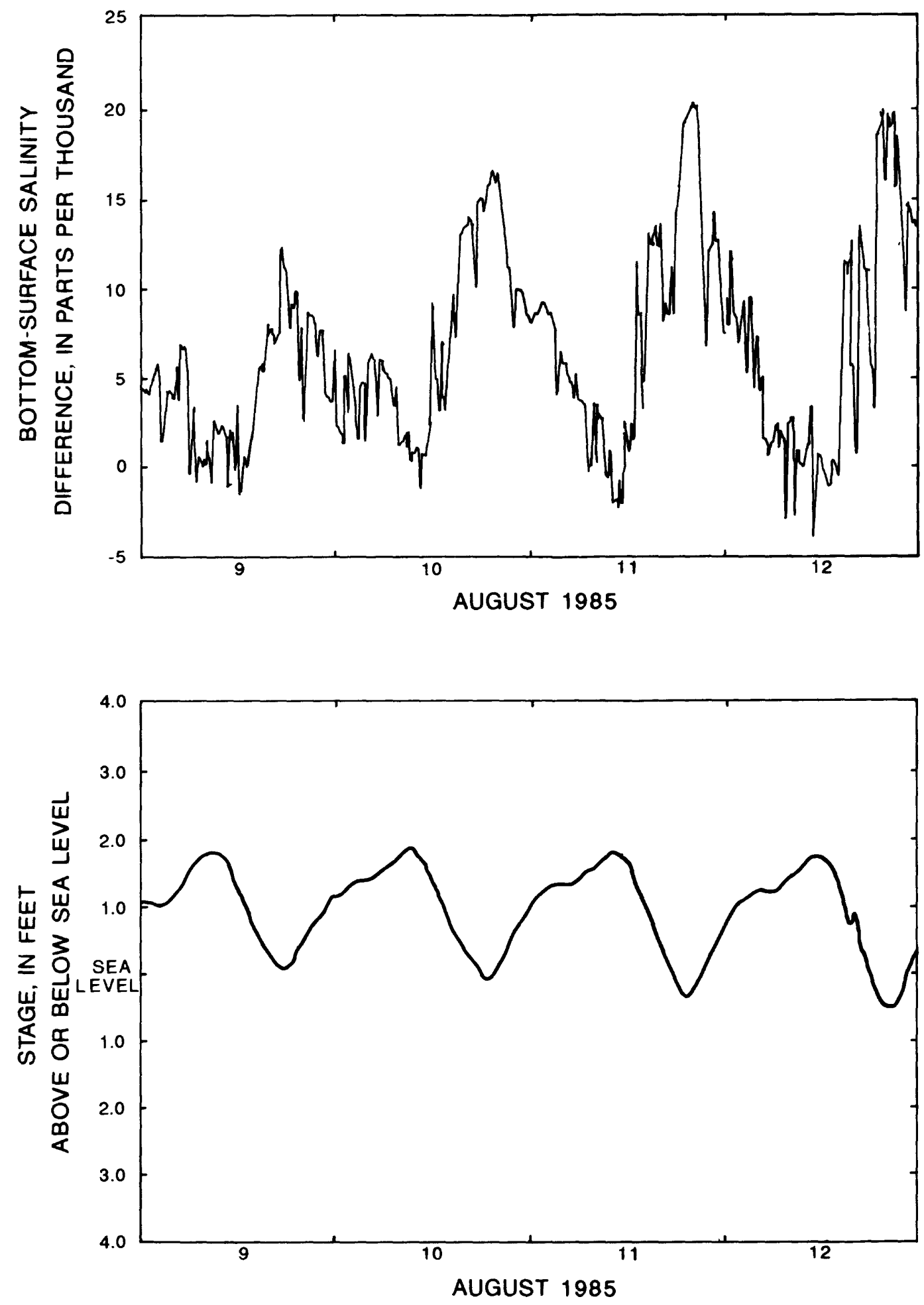

Figure 19.--Difference between near-surface and near-bottom salinity and stage at Punta Gorda, August 9-12, 1985. 


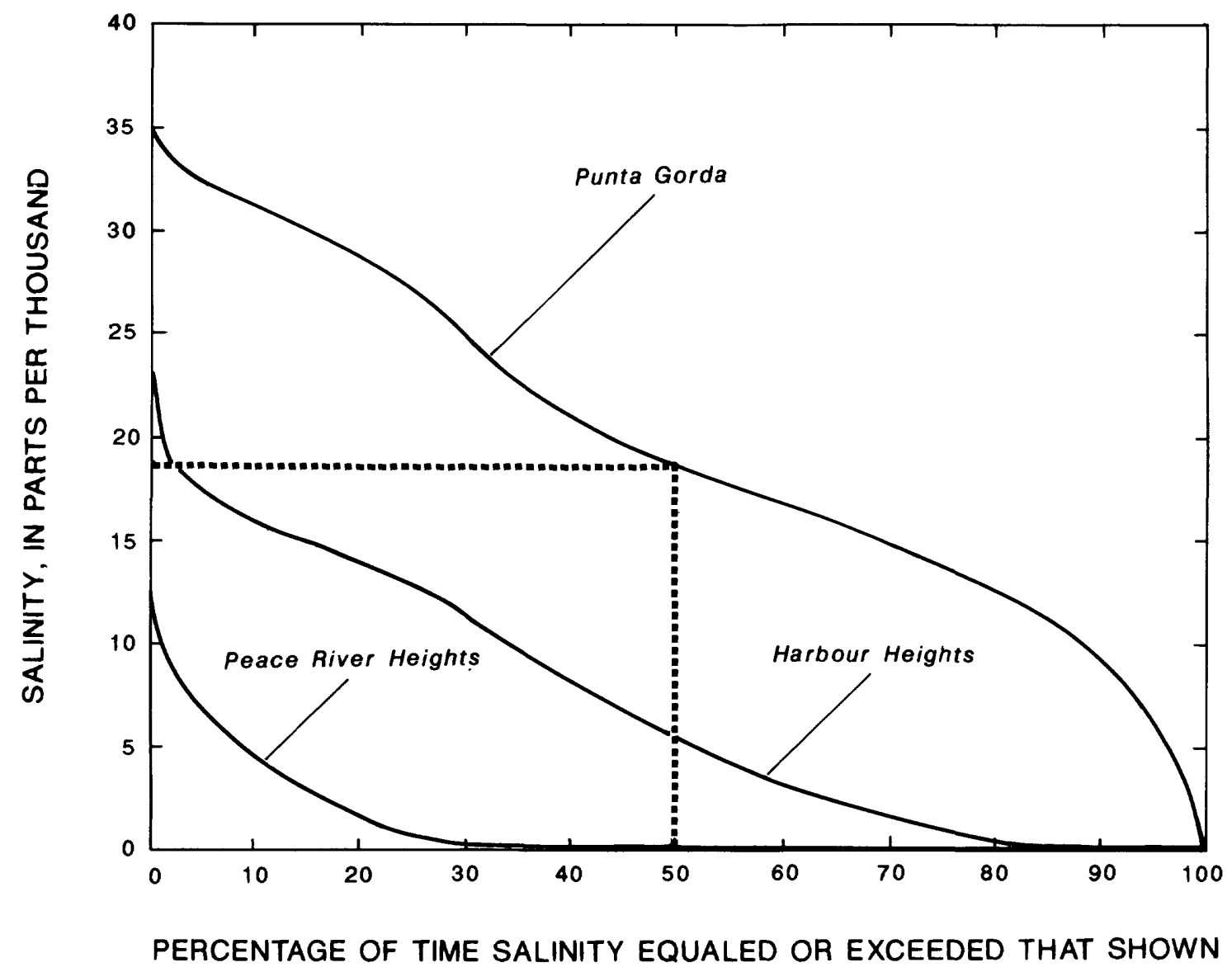

Figure 20.--Duration curves for salinity at three continuous recording gages on the tidal Peace River, April 1983 through December 1985.

Table 2.--Results of regression analyses relating salinity locations to daily mean conductance

\begin{tabular}{|c|c|c|c|c|c|c|c|}
\hline $\begin{array}{l}\text { Dependent } \\
\text { variable } \\
\text { (river } \\
\text { miles) }\end{array}$ & $\begin{array}{l}\text { Independent } \\
\text { variable }\end{array}$ & $\underset{\mathbf{R}^{2}}{\text { Adjusted }}$ & $\begin{array}{l}\text { d Root mean } \\
\text { square error } \\
\text { (river miles) }\end{array}$ & $\begin{array}{l}\text { Degr } \\
\text { of } \\
\text { freed }\end{array}$ & es & |uations & \\
\hline $0.5 \mathrm{ppt}(\mathrm{S})^{1}$ & COND.HH ${ }^{2}$ & 0.83 & 1.5 & 50 & $0.5 \mathrm{ppt}$ river mile & $=0.000368(\mathrm{COND} . \mathrm{HH})$ & +9.47595 \\
\hline $1.0 \mathrm{ppt}(\mathrm{S})$ & COND.HH & .86 & 1.3 & 50 & $1.0 \mathrm{ppt}$ river mile & $=0.000363(\mathrm{COND} . \mathrm{HH})$ & +8.6965 \\
\hline $5.0 \mathrm{ppt}(\mathrm{S})$ & COND.HH & .89 & 1.1 & 48 & $5.0 \mathrm{ppt}$ river mile & $=0.000358($ COND.HH $)$ & +6.25908 \\
\hline $10.0 \mathrm{ppt}(\mathrm{S})$ & COND.HH & .88 & 1.2 & 44 & $10.0 \mathrm{ppt}$ river mile & $=0.000347(\mathrm{COND} . \mathrm{HH})$ & +4.34718 \\
\hline $15.0 \mathrm{ppt}(\mathrm{S})$ & COND.PG ${ }^{3}$ & .81 & 1.7 & 28 & $15.0 \mathrm{ppt}$ river mile & $=0.000342(\mathrm{COND} . \mathrm{PG})$ & -4.87012 \\
\hline 20.0 ppt (S) & COND.PG & .78 & 1.2 & 10 & $20.0 \mathrm{ppt}$ river mile & $=0.000368(\mathrm{COND} \cdot \mathrm{PG})$ & -8.47312 \\
\hline $0.5 \mathrm{ppt}(\mathrm{B})$ & COND.HH & .87 & 1.2 & 49 & $0.5 \mathrm{ppt}$ river mile & $=0.000354($ COND.HH $)$ & +9.89454 \\
\hline $1.0 \mathrm{ppt}(\mathrm{B})$ & COND.HH & .88 & 1.1 & 49 & $1.0 \mathrm{ppt}$ river mile & $=0.000343($ COND.HH $)$ & +9.25809 \\
\hline $5.0 \mathrm{ppt}(\mathrm{B})$ & COND.HH & .89 & 1.1 & 49 & 5.0 ppt river mile & $=0.000333(\mathrm{COND} . \mathrm{HH})$ & +7.26964 \\
\hline 10.0 ppt (B) & COND.HH & .83 & 1.2 & 49 & $10.0 \mathrm{ppt}$ river mile & $=0.000303(\mathrm{COND} . \mathrm{HH})$ & +5.82974 \\
\hline $15.0 \mathrm{ppt}(\mathrm{B})$ & COND.PG & .82 & 1.3 & 38 & $15.0 \mathrm{ppt}$ river mile & $=0.000261(\mathrm{COND} . \mathrm{PG})$ & -0.74846 \\
\hline 20.0 ppt (B) & COND.PG & .88 & .9 & 24 & $20.0 \mathrm{ppt}$ river mile & $=0.000230(\mathrm{COND} \cdot \mathrm{PG})$ & -1.58117 \\
\hline
\end{tabular}

${ }_{2}^{1}(S)=$ surface salinity; $(B)=$ bottom salinity.

${ }_{3} \mathrm{COND} . \mathrm{HH}=$ daily mean conductance at Peace River at Harbour Heights.

3 COND.PG $=$ daily mean conductance at Peace River at Punta Gorda. 


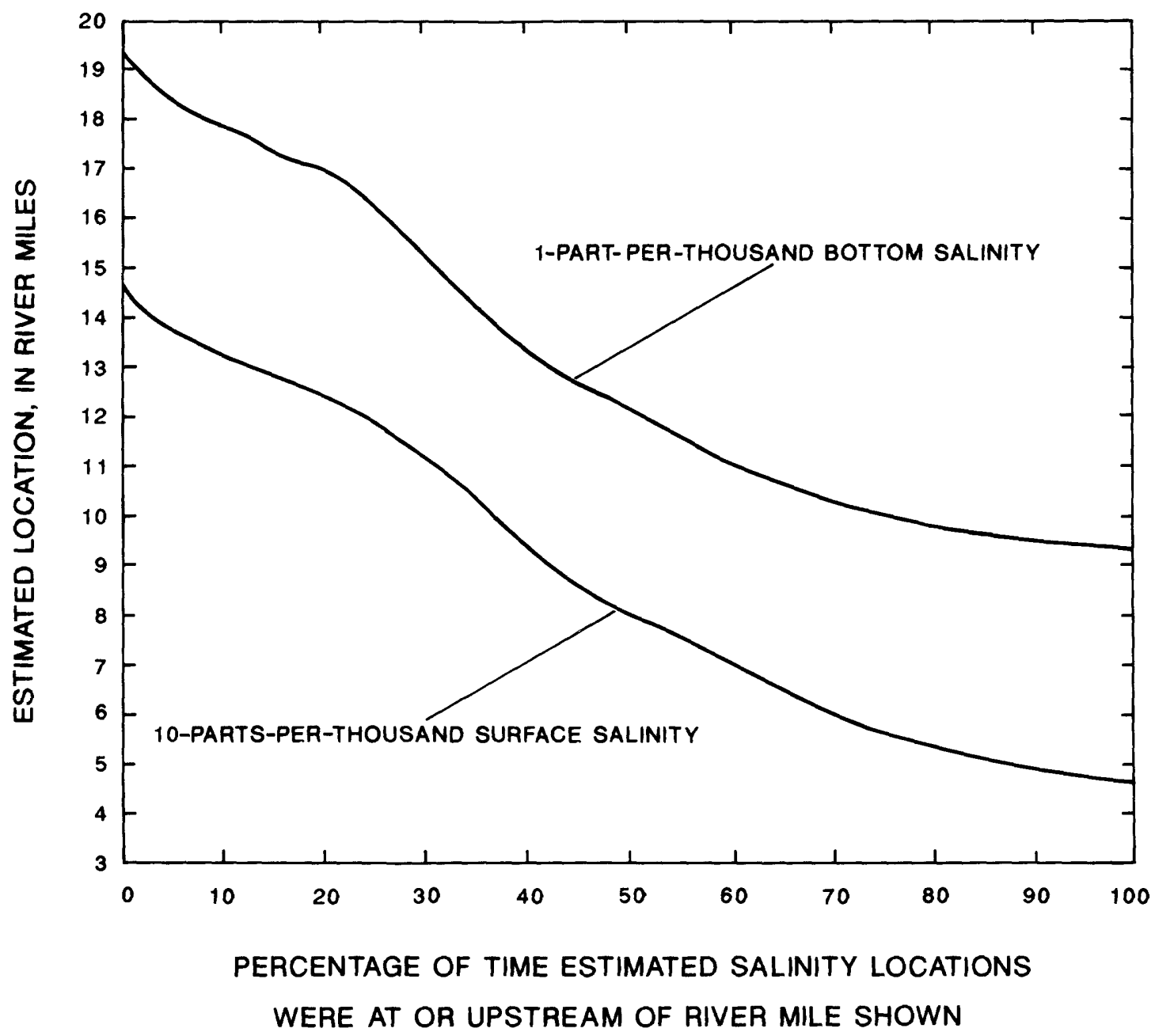

Figure 21.--Duration curves for the estimated locations of the bottom 1-part-per-thousand salinity and the surface 10-parts-per-thousand salinity, April 1983 through December 1985.

demonstrates that the tidal river is typically not well-mixed vertically.

To illustrate the salinity distribution during periods of lower inflow, the 10-percent frequency locations of the estimated daily high-tide salinities are shown in figure 23. Bottom salinities are upstream of the surface salinities, indicating some stratification still exists under these conditions. The surface 10-percent frequency salinities are an average of 5.6 miles upstream of their median locations, and bottom salinities are an average of 5.3 miles upstream.
The stratification effects seen in figures 22 and 23 are for high-tide conditions. As demonstrated previously (fig. 19), the magnitude of surface to bottom salinity differences is smallest during high tide and greatest during low tide at Punta Gorda. Assuming the same basic pattern of stratification occurs throughout the tidal Peace River, the difference between locations of the surface and bottom salinities should be even greater for low-tide conditions. 


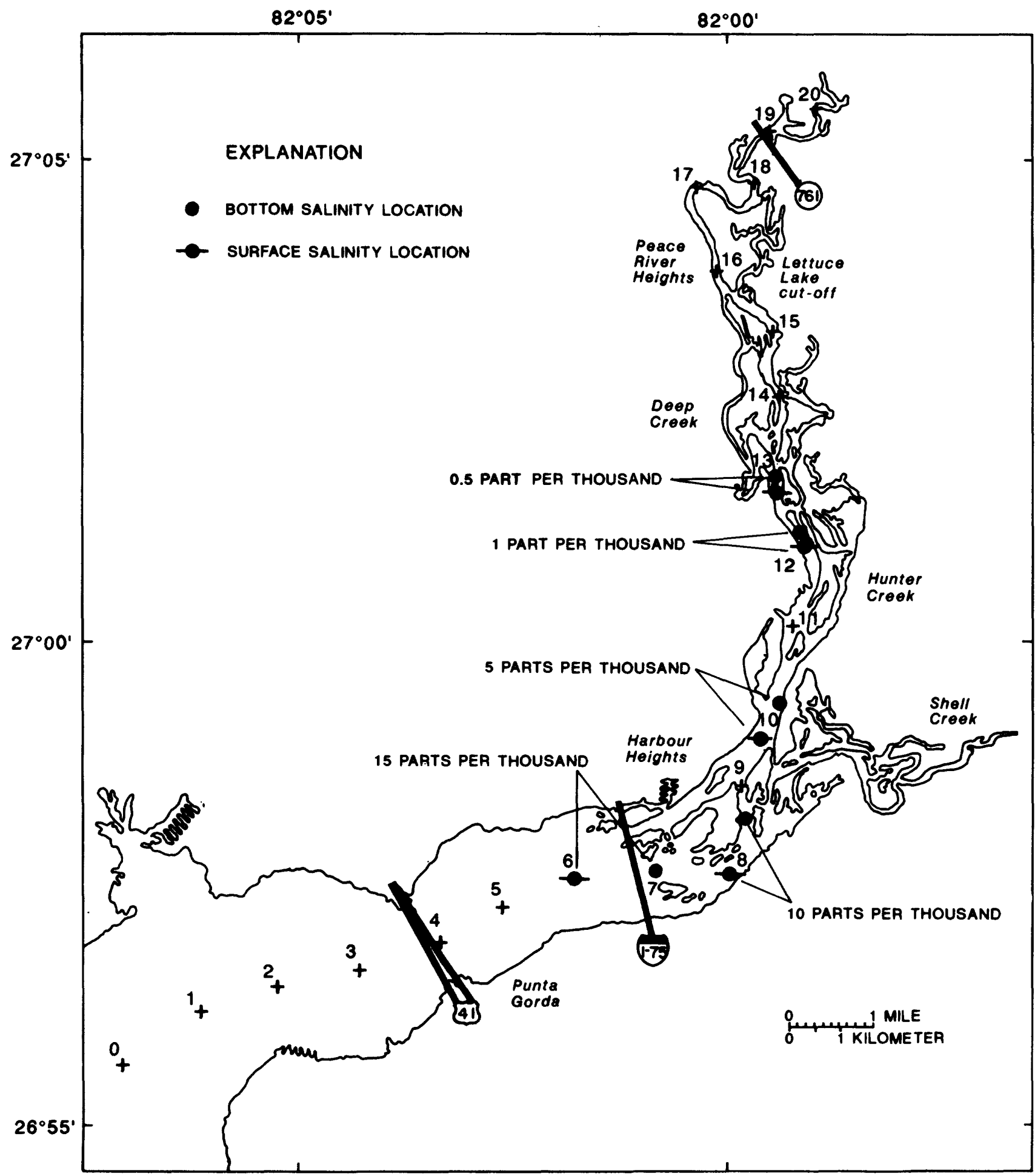

Figure 22.--Fifty-percent frequency locations of the estimated daily high-tide salinities, April 1983 through December 1985. 


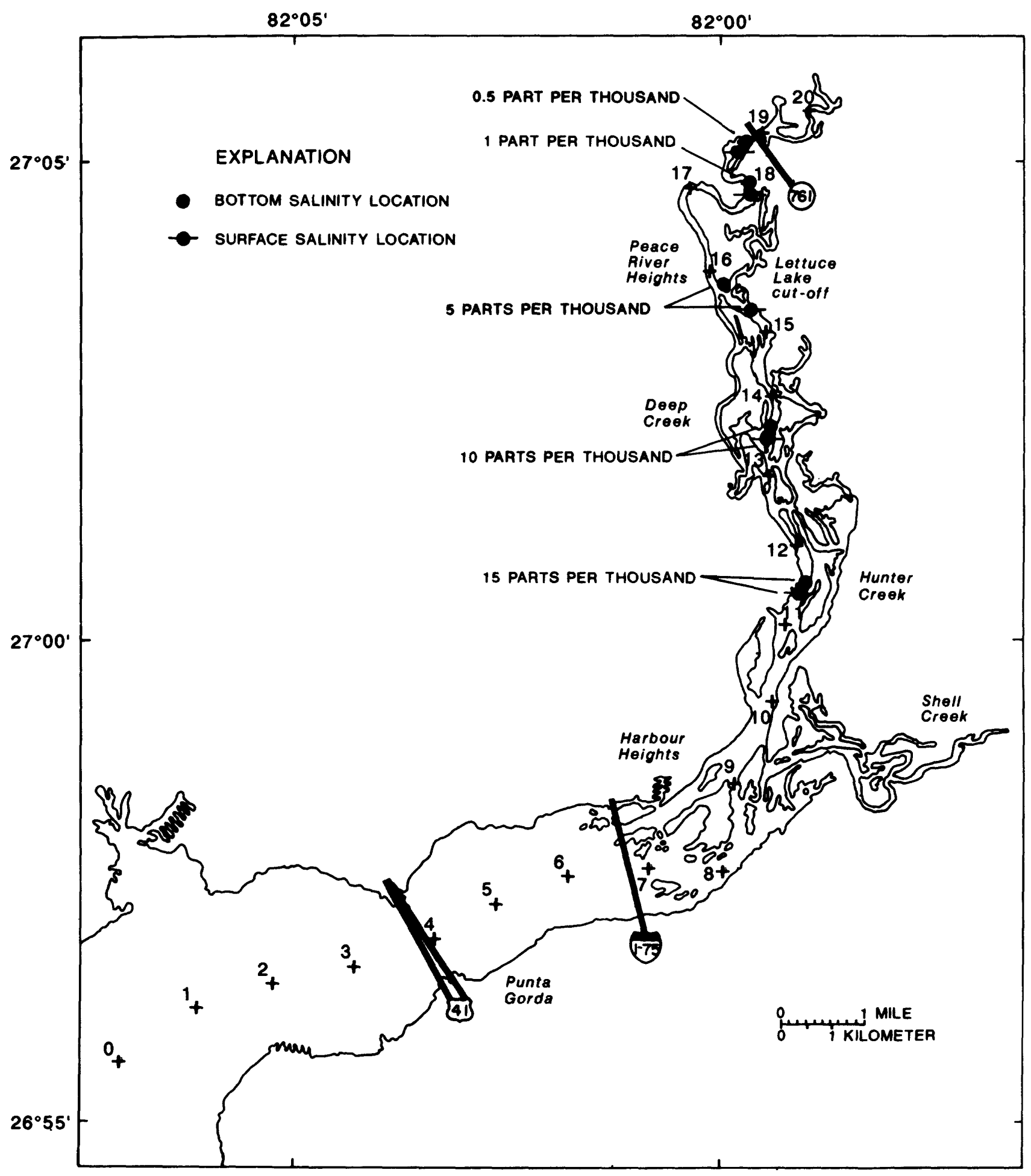

Figure 23.--Ten-percent frequency locations of the estimated daily high-tide salinities, April 1983 through December 1985. 
Salinity Locations Estimated from Freshwater Inflow and Tidal Stages

An in-depth analysis was made to determine the relation between freshwater inflow and tidal stage on salinity locations in the river. The following independent variables were evaluated in the analysis:

Discharge at the Peace River at Arcadia, Horse Creek near Arcadia, Joshua Creek at Nocatee, Shell Creek near Punta Gorda (fig. 5):

- daily mean discharge at each gage;

- cumulative totals of discharge for

$2,3,4,5,10 \ldots 50$ days at each gage; and

- daily mean discharge at each gage, lagged 1 to 3 days.

Tidal stage at Peace River at Punta Gorda gage (fig. 2):

- daily mean tidal stage,

- daily maximum tidal stage, and

- daily range in tidal stage.

All combinations of these variables were tested at the 5-percent significance level. Regressions were run to determine locations of surface and bottom salinities ranging from 0.5 to $20 \mathrm{ppt}$. Mean daily discharge records were available for all field salinity measurements made between June 1982 and September 1985. Tide-stage data were available for most field measurements made May 1983 through September 1985. Missing tide-stage record resulted in fewer available salinity measurements for use in regression analyses that include tide. For example, for the regression of 0.5 -ppt surface salinity locations, 61 field measurements were available for use in regressions involving daily discharge alone. When tide was included as a variable, only 47 of the field measurements could be used.

Table 3 summarizes the results of regression analyses. The equations shown in table 3 were chosen as the best representation of the relation between salinity location and freshwater inflows and tide.

Salinity in the tidal river is related to antecedent salinity conditions as well as current freshwater inflows. Because of this, a cumulative sum of discharge proved to be more repre- sentative of inflow than either same day or lagged discharge. The effects of freshwater travel time from the gages to the tidal river also were minimized by using a cumulative discharge.

The many combinations of cumulative discharges often resulted in similar regression results. When the $R^{2}$ and RMSE were similar, the smallest cumulation of daily discharge was chosen for table 3. For surface salinity locations, 5-day cumulative discharges for the Peace River and Horse Creek were usually the most significant variables. For bottom salinities, a longer cumulation of discharge from two or three streams yielded the best results.

Shell Creek discharges were not significant at the 5-percent level in any of the surface salinity analyses. Field measurements of salinity were made at the center of the river, whereas Shell Creek waters probably flow near the left bank of the tidal river. Shell Creek discharge undoubtably affects salinity patterns in the lower tidal river, but its effects generally were not apparent using data from midstream. Although tide is intuitively an important factor in determining any salinity location, it was not a significant variable in the regression analyses for determining the surface 15-ppt and 20-ppt locations or the bottom 20-ppt locations.

For both the near-surface and near-bottom salinity locations, $R^{2}$ generally decreased from the $0.5 \mathrm{ppt}$ to the higher salinity locations (table 3 ). The influence that freshwater inflows and tide have on salinity become more complex toward the mouth of the river where the higher salinities were typically located. This complexity resulted in a poorer fit of the data to measured freshwater inflow and tide. Although the regression of the 20-ppt salinity at high tide has a higher $\mathrm{R}^{2}$ than for some of the lower salinities, the results must be viewed with caution because fewer data points were used in the 20-ppt regressions than were used in the other salinity regressions.

The valid ranges of discharges and tides for use in the regression equations (table 3 ) are shown in table 4. These equations should be used only to estimate high-tide salinity locations under conditions similar to those during the June 1982 through September 1985 field measurement period. 
Table 3.--Regression equations relating salinity location to freshwater inflow and daily mean stage in the tidal Peace River

\begin{tabular}{|c|c|c|c|c|c|}
\hline $\begin{array}{c}\text { Dependent } \\
\text { variable } \\
\text { (river } \\
\text { miles) }\end{array}$ & $\underset{\mathbf{R}^{2}}{\text { Adjusted }}$ & $\begin{array}{l}\text { Root mean } \\
\text { square } \\
\text { error } \\
\text { (river } \\
\text { miles) }\end{array}$ & $\begin{array}{l}\text { Degrees } \\
\text { of } \\
\text { freedom }\end{array}$ & & Equations \\
\hline \multicolumn{6}{|c|}{ Surface salinities: } \\
\hline $0.5 \mathrm{ppt}$ & 0.90 & 1.1 & 46 & $0.5 \mathrm{ppt} R \mathrm{RM}$ & $\begin{array}{c}=-3.9695^{*} \log (\text { Peace } 5 \text {-day })-2.45071^{*} \log (\text { Horse } 5 \text {-day }) \\
+1.26177^{*} \text { tide }+18.22004\end{array}$ \\
\hline $1.0 \mathrm{ppt}$ & .87 & 1.3 & 46 & 1.0 ppt RM & $\begin{array}{c}=-2.65644^{*} \log (\text { Horse } 5 \text {-day })-3.395330^{*} \log (\text { Peace } 5 \text {-day }) \\
+1.24264^{*} \text { tide }+16.17333\end{array}$ \\
\hline $5.0 \mathrm{ppt}$ & .73 & 1.8 & 44 & $5.0 \mathrm{ppt} \mathrm{RM}$ & $\begin{array}{c}=-2.82885^{*} \log (\text { Horse5-day })-2.49646^{*} \log (\text { Peace } 5 \text {-day }) \\
+1.45436^{*} \text { tide }+8.81916\end{array}$ \\
\hline $10.0 \mathrm{ppt}$ & .65 & 2.0 & 41 & $10.0 \mathrm{ppt}$ RM & $\begin{array}{c}=-2.52445^{*} \log (\text { Horse5-day }) \cdot 2.74303^{*} \log (\text { Peace } 5 \text {-day }) \\
+1.76489^{*} \text { tide }+3.50346\end{array}$ \\
\hline $15.0 \mathrm{ppt}$ & .60 & 2.2 & 40 & 15.0 ppt RM & $=-4.43894 * \log ($ Horse30-day $)+19.95678$ \\
\hline $20.0 \mathrm{ppt}$ & .80 & 1.2 & 18 & 20.0 ppt RM & $\begin{array}{c}=-10.44186^{*} \log (\text { Peace } 10 \text {-day })+2.05960 * \log (\text { Joshual0-day }) \\
+2.23614^{*} \log (\text { Horse10-day })+31.29000\end{array}$ \\
\hline \multicolumn{6}{|c|}{ Bottom salinities: } \\
\hline $0.5 \mathrm{ppt}$ & .90 & 1.1 & 46 & $0.5 \mathrm{ppt} \mathrm{RM}$ & $\begin{array}{c}=-3.90638^{*} \log (\text { Peace5-day })-2.21789^{*} \log (\text { Horse } 5 \text {-day }) \\
+1.10797^{*} \text { tide }+19.43200\end{array}$ \\
\hline $1.0 \mathrm{ppt}$ & .86 & 1.2 & 46 & 1.0 ppt RM & $\begin{array}{c}=-3.35073^{*} \log (\text { Peace5-day })-2.23592^{*} \log (\text { Horse } 5 \text {-day }) \\
+1.30210^{*} \text { tide }+14.84343\end{array}$ \\
\hline $5.0 \mathrm{ppt}$ & .79 & 1.5 & 46 & $5.0 \mathrm{ppt} \mathrm{RM}$ & $\begin{array}{c}=-3.57792 * \log (\text { Horse } 30 \text {-day })-1.41819^{*} \log (\text { Shell30-day }) \\
+1.47894^{*} \text { tide }+11.60250\end{array}$ \\
\hline $10.0 \mathrm{ppt}$ & .75 & 1.6 & 46 & $10.0 \mathrm{ppt} R M$ & $\begin{array}{c}=-2.95559^{*} \log (\text { Horse } 30 \text {-day })-1.72749^{*} \log (\text { Shell30-day }) \\
+2.09684^{*} \text { tide }+2.34131\end{array}$ \\
\hline $15.0 \mathrm{ppt}$ & .58 & 2.0 & 44 & 15.0 ppt RM & $\begin{array}{r}=-5.19045^{*} \log (\text { Peace15-day })+3.30380^{*} \log (\text { Joshua } 15 \text {-day }) \\
-2.20854^{*} \log (\text { Shell15-day })+2.23416^{*} \text { tide }+1.25561\end{array}$ \\
\hline $20.0 \mathrm{ppt}$ & .77 & 1.2 & 35 & 20.0 ppt RM & $\begin{array}{c}=-7.08882^{*} \log (\text { Peace } 15 \text {-day })+2.93679 * \log (\text { Joshua } 15 \text {-day }) \\
+24.63210\end{array}$ \\
\hline
\end{tabular}

where $0.5 \mathrm{ppt}$ RM is the location of the 0.5 -part-per-thousand salinity, in river miles; $\log$ (Peace5-day), $\log$ (Horse5day), $\log$ (Shell30-day), and $\log$ (Joshua15-day) are the base 10 logarithms of the cumulative discharge for the indicated number of days at the Peace River at Arcadia, Horse Creek near Arcadia, Shell Creek near Punta Gorda, and Joshua Creek at Nocatee, respectively; and tide is the daily mean stage for the Peace River at Punta Gorda. 
For example, applying these equations to periods prior to completion of the Interstate Highway 75 bridge across the Peace River in June 1981 would not be valid.

Long-term trends in streamflow at the Peace River at Arcadia gaging station indicate a significant decreasing trend in annual mean discharge (Hammett, 1988). If this trend continues, salinity characteristics in the tidal river also will change. To illustrate the effects of decreased streamflow on salinity in the tidal Peace River, estimated locations of the surface 0.5 -ppt salinity for selected 2-year low-flow intervals were calculated based on the sum of daily mean discharges at the four gaging stations shown in figure $\mathbf{5}$ and stage. The following equation was developed so that 2-year low-flow intervals shown in figure 7 could be used in the analysis.

$$
\begin{gathered}
\text { 0.5-ppt location }=-7.15042 \text { log.total } \\
+1.80824 \text { stage }+13.67107
\end{gathered}
$$

where

log.total = base 10 logarithm of the total gaged freshwater daily mean inflow, and

stage $=$ daily mean stage at Punta Gorda plus a 10.00 -foot datum correction.

Table 4.--Range of discharges and tides used in regression analyses

\begin{tabular}{|c|c|c|}
\hline & Maximum & Minimum \\
\hline \multicolumn{3}{|l|}{ Daily mean discharge at: } \\
\hline Peace River at Arcadia (02296750) & 13,900 & 34 \\
\hline Joshua Creek at Nocatee $(02297100)$ & 1,860 & 4.2 \\
\hline Horse Creek near Arcadia (02297310) & 3,380 & 64 \\
\hline Shell Creek near Punta Gorda (02298202) & 4,670 & 3.1 \\
\hline \multicolumn{3}{|l|}{ 5-day sum of discharge at: } \\
\hline Peace River at Arcadia (02296750) & 73,500 & 186 \\
\hline Horse Creek near Arcadia (02297310) & 17,220 & 6.2 \\
\hline \multicolumn{3}{|l|}{ 10-day sum of discharge at: } \\
\hline Peace River at Arcadia (02296750) & 94,000 & 379 \\
\hline Joshua Creek at Nocatee (02297100) & 21,100 & 48 \\
\hline Horse Creek near Arcadia (02297310) & 31,100 & 12 \\
\hline \multicolumn{3}{|l|}{ 15-day sum of discharge at: } \\
\hline Peace River at Arcadia (02296750) & 156,000 & 693 \\
\hline Joshua Creek at Nocatee $(02297100)$ & 21,400 & 67 \\
\hline Shell Creek near Punta Gorda (02298202) & 49,900 & 55 \\
\hline \multicolumn{3}{|l|}{ 30-day sum of discharge at: } \\
\hline Horse Creek near Arcadia (02297310) & 52,500 & 85 \\
\hline Shell Creek near Punta Gorda (02298202) & 67,700 & 148 \\
\hline Daily mean tide at Punta Gorda, in feet above sea level & 1.44 & -0.64 \\
\hline
\end{tabular}

[All values are in cubic feet per second unless otherwise noted] 
The $\mathrm{R}^{2}$ for this regression was 0.88 and the standard error was 1.3 river miles.

Equation 3 was used to estimate locations of the 0.5-ppt salinity for the 7-, 15-, 30-, 60-,90-, and 183-day low flows at the 2-year recurrence interval. Discharge for each low flow was taken from figure 7, and an average daily stage of 0.61 foot at Punta Gorda was used. The 2-year low flows were then reduced from 0 to 100 percent and the surface 0.5 -ppt locations recalculated to determine how far upstream the estimated high-tide salinity locations would move. Maximum upstream movement during periods of zero discharge is linited by tide stage and streambed elevation. The maximum upstream location of saltwater is estimated to be river mile 32 where the streambed elevation approximately equals the maximum expected tide.
Figure 24 shows the effects of reductions in the 2-year low flows on the surface 0.5 -ppt locations. For example, if the 7-day, 2-year low flow is reduced by 50 percent (lowered $58 \mathrm{ft}^{3} / \mathrm{s}$ ), the estimated high-tide surface 0.5 -ppt location would move 2.2 miles upstream (from river mile 18.1 to river mile 20.3). If the 30-day, 2-year low flow is reduced by 50 percent (lowered $81 \mathrm{ft}^{3} / \mathrm{s}$ ), an upstream movement of 2.1 miles would occur (from river mile 17.1 to river mile 19.2).

\section{Salinity Stratification Regression Analyses}

The degree of vertical salinity stratification is indicated by the differences between near-surface and near-bottom salinity. An analysis of these differences at the river mouth was made for different freshwater inflow and tidal conditions using multiple regression techniques. Tidal stages were not a significant variable in any combination of inflow and tide. Five-day cumulative sums of

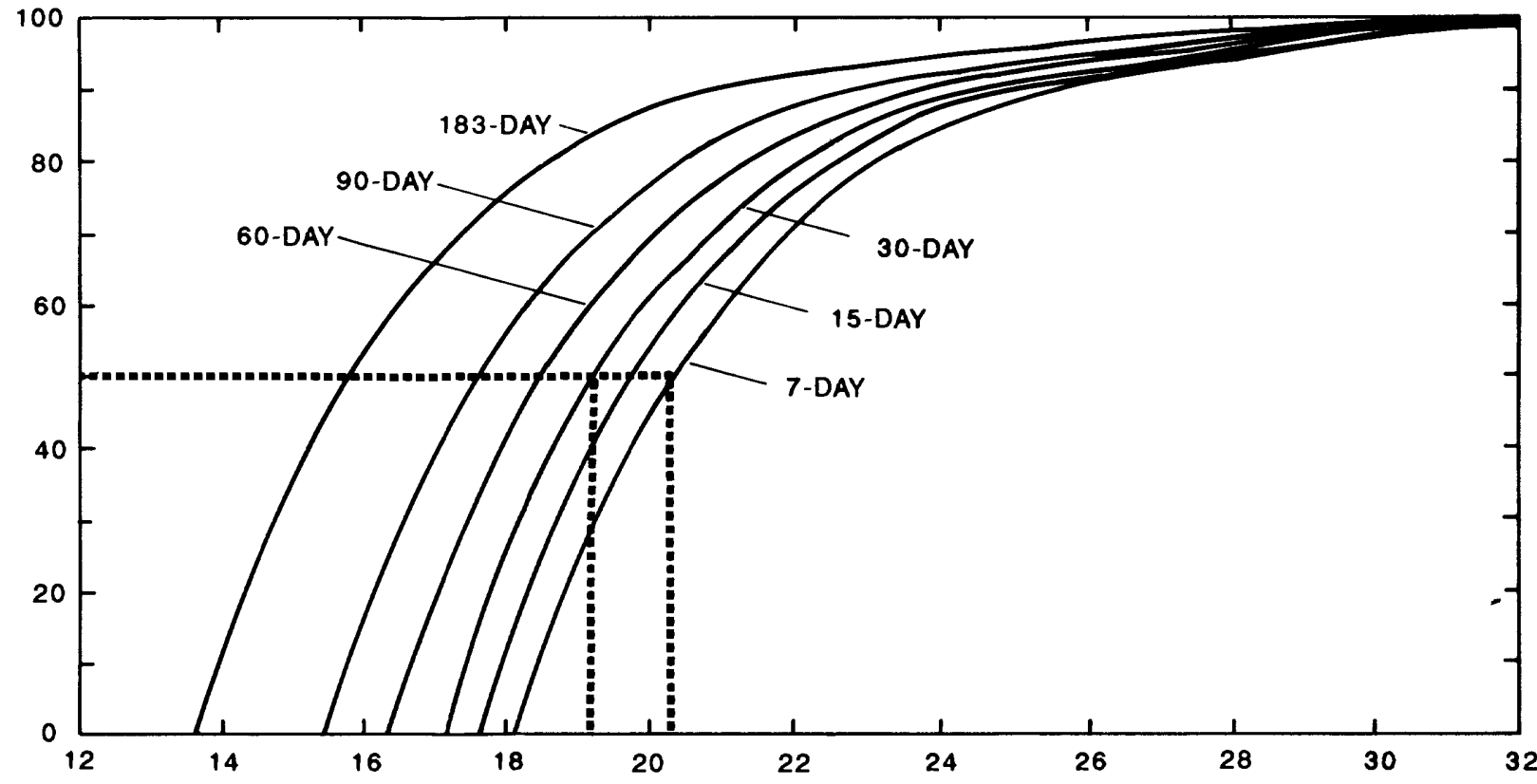

LOCATION OF THE SURFACE 0.5-PART-PER-THOUSAND SALINITY, IN RIVER MILES

Figure 24.--Effects of reductions in the 2-year low flows on the locations of the high-tide surface salinity of 0.5 -part-per-thousand. 
discharge at the Peace River at Arcadia yielded an $R^{2}$ of 0.92 and an RMSE of 1.8 ppt using the following equation:

$$
\begin{gathered}
\left.\Delta \text { salinity }=0.8471 \times 10^{-3} \text { (Peace 5-day }\right) \\
-0.1300 \times 10^{-7}(\text { Peace 5-day })^{2}
\end{gathered}
$$

where

$$
\begin{gathered}
\Delta \text { salinity = } \begin{array}{l}
\text { bottom salinity minus } \\
\text { surface salinity, in parts } \\
\text { per thousand; }
\end{array}
\end{gathered}
$$

Peace 5-day $=$ cumulative total of discharge for 5 days at Peace River at Arcadia, in cubic feet per second-days.

The 5-day sum of discharge during the June 1982, 10-year flood $\left(73,500 \mathrm{ft}^{3} / \mathrm{s}\right.$ days $)$ at Peace River at Arcadia was not included in the regression plotted in figure 25 . The regression was used to plot salinity differences through 30,000 $\mathrm{ft}^{3} / \mathrm{s}$-days and is shown as a solid line. The probable stratification-discharge relation above this point is shown as the dashed line extending from 30,000 to $73,500 \mathrm{ft}^{3} / \mathrm{s}$-days.

\section{Freshwater Replacement Time}

Freshwater replacement time (FRT), defined as the time for the total volume of freshwater in a water body to be replaced by freshwater inflow, can be used in certain circumstances as an approximation of flushing time or water residence time (Pilson, 1985). The usefulness of the approximation increases where waters are well mixed and where wind, tide, and freshwater inflow approach steady-state conditions.

FRT was calculated in the tidal Peace River for a variety of freshwater inflows to assess the effects of these inflows on water transport and

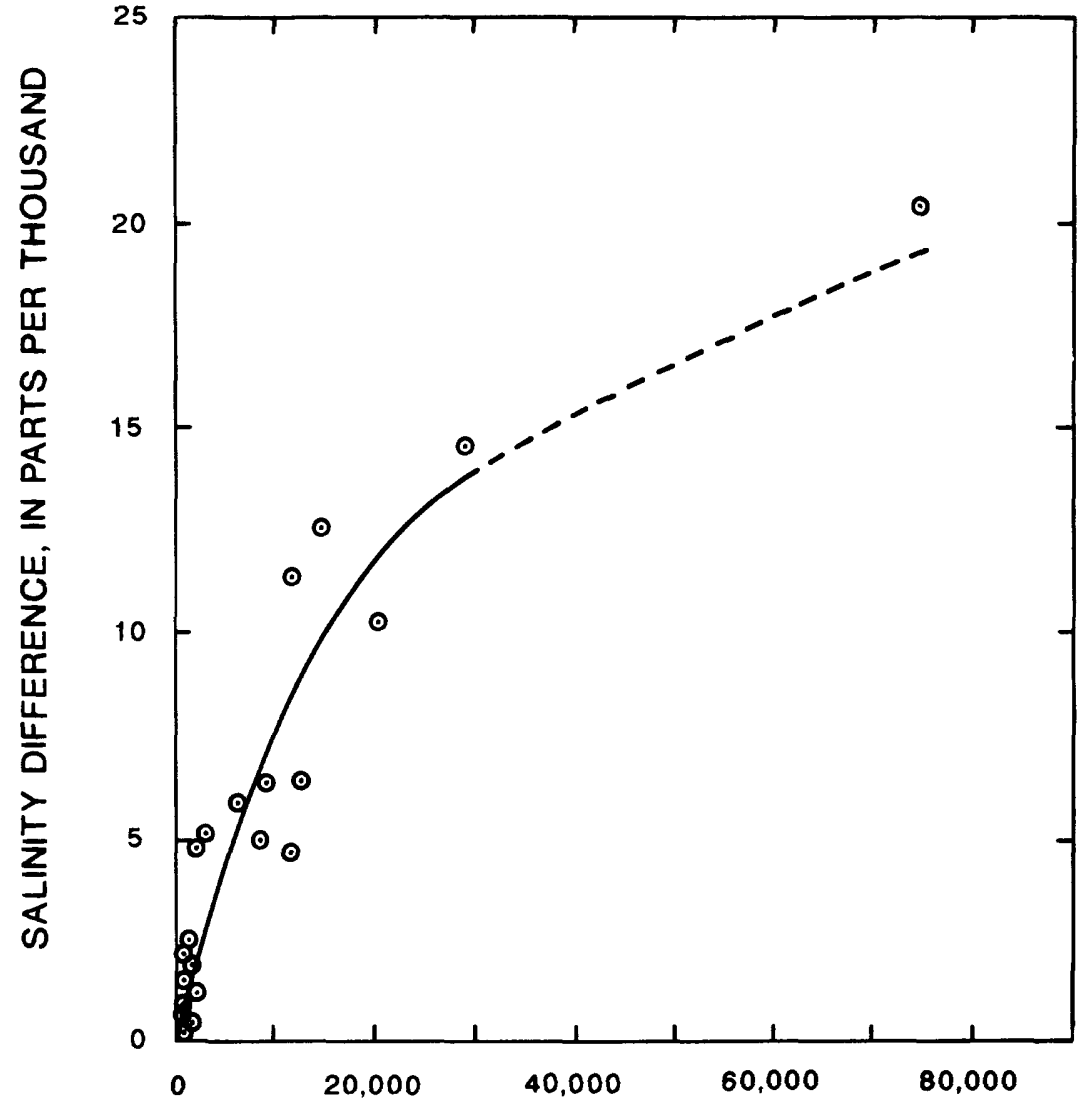

PEACE RIVER DISCHARGE, 5-DAY SUM, IN

\section{CUBIC FEET PER SECOND-DAYS}

Figure 25.--Difference between surface and bottom salinity at river mile 0 as a functon of 5-day sums of discharge at the Peace River at Arcadia. 
FRT approximates water residence time probably varies depending on conditions in the river. Daily or weekly variability in wind speed and direction probably have an averaging effect on water transport, but undoubtedly strong, sustained winds, particularly blowing along the axis of the river, affect net water transport on a time scale not consistent with day-to-day steady-state transport. Tidal amplitude, tidal prism, and tidal velocity vary during the lunar cycle, but their effects on water transport will tend to average out over several weeks or longer. Freshwater inflow can vary significantly from day to day, particularly during storm runoff, but becomes more constant as flows decline toward base flows.

There are a number of sources of error and uncertainty in the calculation of FRT (Pilson, 1985). It is not certain how well a salinity value(s) at one point in time represents salinity in a river section or in the seawater source, whether mean tide is the best value to use to determine river volume, or whether the previous 30 -day period is the best time interval to determine average inflow. In any case, FRT applies only to the river reach as defined by the boundaries, assumptions, and estimates used.

FRT in the tidal Peace River for monthly average freshwater inflows ranged from about 40 days during extended low-flow periods (less than $200 \mathrm{ft}^{3} / \mathrm{s}$ ) to about 2 days during high freshwater runoff (about 12,000 $\mathrm{ft}^{3} / \mathrm{s}$ ) (fig. 26). Values for FRT at high inflows do not adequately represent freshwater flushing or residence time because parts of the tidal river were stratified and freshwater probably did not replace the deeper, salty water for extended periods. Values of FRT at low to moderate freshwater inflows may better approximate freshwater flushing and residence time, but uncertainties related to mixing and steadystate conditions preclude equivalency.

Some confidence in the use of FRT as an approximation of residence time is provided by a comparison with the movement of dye during a time-of-travel study in July 1984. The dye peak moved downstream from river mile 20 to 10 in about 5 days. FRT for this 10 -mile reach, computed from a salinity transect on the same day the dye was released, also was about 5 days.

\section{SUMMARY}

The Peace River in southwestern Florida is the primary source of freshwater to Charlotte Harbor, and the freshwater is essential in maintaining estuarine conditions in the harbor. The tidal reach of the river is the connecting link between incoming freshwater and the estuarine waters of Charlotte Harbor. The 26-mile tidal reach consists of a complex system of off-channel storage areas, numerous channels interconnected with the main stem, and a flood plain that commonly exceeds 1 mile in width. Discharge to the tidal reach during 1983-85 averaged $1,680 \mathrm{ft}^{3} / \mathrm{s}$.

Hydraulic characteristics in the tidal river are influenced primarily by fluctuations in tidal stage. Average tidal range during the study was 2.2 feet. During low freshwater inflows, tidal peaks and troughs proceed from Punta Gorda to State Road 761 in about 1 hour and 50 minutes, or $8.2 \mathrm{mi} / \mathrm{h}$.

Flow reversals due to tide are common in the tidal Peace River except during periods of high freshwater inflows when reversals diminish or disappear. At State Road 761, flow reversals cease as total gaged inflow upstream increases above $1,000 \mathrm{ft}^{3} / \mathrm{s}$. Tidally induced discharge at State Road 761 was about five times the total gaged inflow in July 1984. During the same period, tidally induced discharge at river mile 11.5 was about seven times greater than freshwater inflows. Reverse flows were only slightly less than downstream flows, indicating that tidal influences generate significant movement of water independent of inflow to the tidal reach.

Velocities are typically low throughout the tidal reach. Velocities were less than $0.3 \mathrm{ft} / \mathrm{s}$ more than half the time at State Road 761 during December 1985 through May 1986.

Salinity characteristics in the tidal river are influenced primarily by freshwater inflows, tide, and harbor salinity. Wind effects may occasionally become important by altering normal tidal patterns. Short-term (daily) salinity fluctuations are due to tide. Smallest daily fluctuations occur in the upstream reaches of the tidal river, increasing toward the mouth. Long-term salinity fluctuations are due to freshwater inflows.

Vertical salinity stratification is a common characteristic of the tidal river. Stratification is 


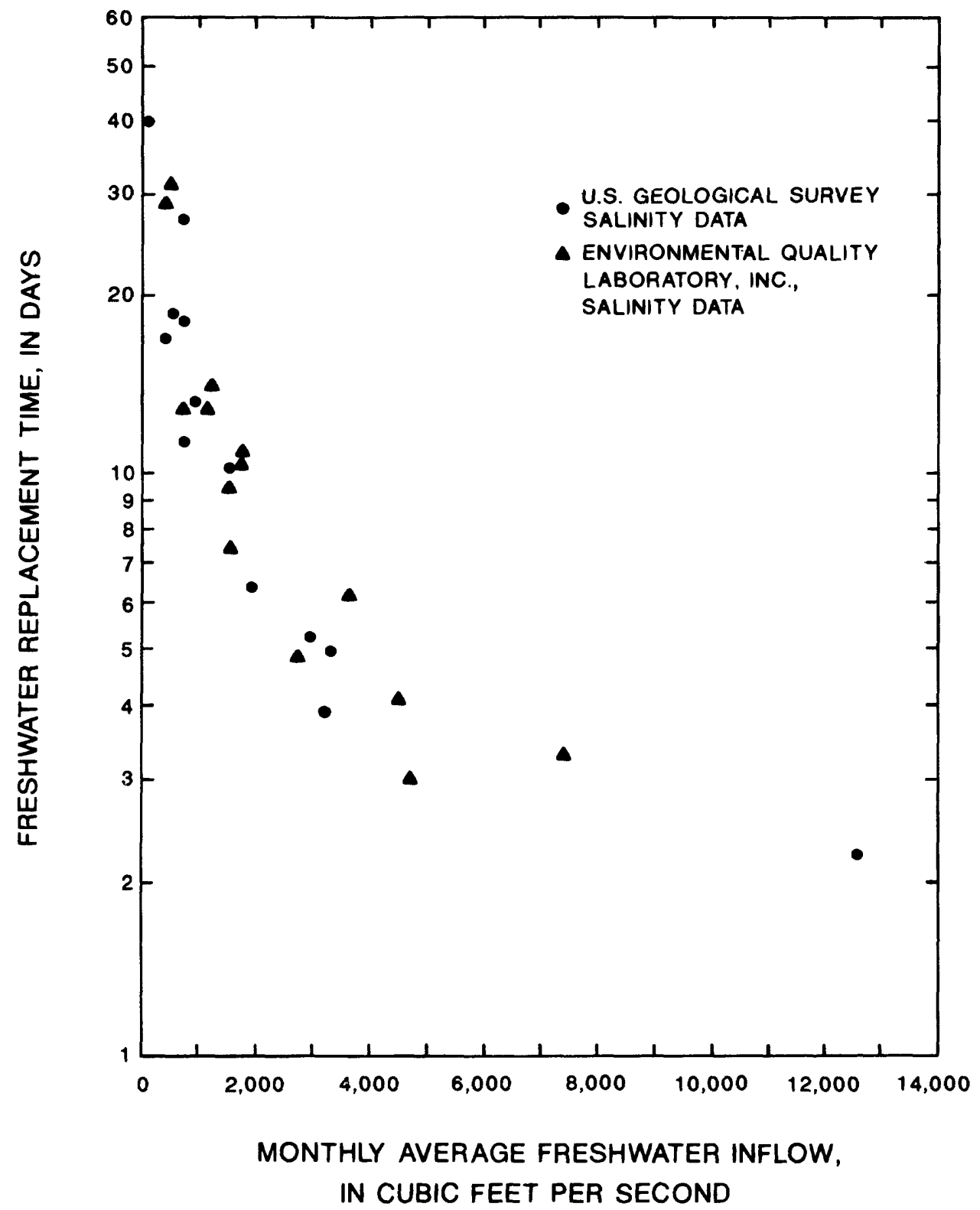

Figure 26.--Relation between freshwater replacement time and monthly average freshwater inflow in the tidal Peace River. 
minimal at low freshwater inflows and increases in proportion to increasing inflows. Short-term stratification patterns at a site vary with tidal stage. The greatest stratification occurs just after the low tide, whereas the least stratification occurs at high tide.

Surface salinities, and to a lesser extent near-bottom salinities, fluctuate with tidal stage. Salinities generally peak around high tide and decrease to a daily minimum around low tide. During low freshwater inflows, surface salinities do not peak, but rather, the peaks flatten out. Near-bottom salinities reach a maximum around high tide, remain elevated, but do not usually peak. This pattern occurs regardless of inflow conditions.

Regression analyses of surface and bottom salinity patterns in the tidal river indicated that gaged inflow from the Peace River at Arcadia and Horse Creek near Arcadia and daily mean tide were the most significant explanatory variables (at the 5-percent probability level) in predicting the high-tide locations of various salinities. Gaged inflows from Shell Creek and Joshua Creek were only occasionally significant. For all regressions, a cumulative sum of discharge for 5 to $\mathbf{3 0}$ days resulted in the highest coefficient of determination values and the lowest root mean square error. Because salinity conditions are related to antecedent salinities as well as current freshwater inflows, discharge summed over a period of days provided a way to account for antecedent discharge conditions (and indirectly, antecedent salinity conditions). Cumulative discharge values also minimized the effects of variable freshwater travel times to the tidal river.

A permanent reduction of streamflow upstream of the tidal Peace River would induce upstream movement of saltwater. For example, if the long-term, 7-day, 2-year low flow is reduced by 50 percent, the high-tide surface 0.5 -ppt salinity would move 2.2 miles upstream. Maximum upstream migration of saline waters would be to around river mile 32 where the streambed elevation approximately equals the normal maximum tide.

Freshwater replacement time, the time for the total volume of freshwater in the tidal river to be replaced by freshwater inflow, ranged from about 2 days during high inflows to about 40 days during low-flow periods.

\section{REFERENCES}

Environmental Quality Laboratory, Inc., 1982, Hydrobiological monitoring program report for the period from March 1981 through February 1982 covering the lower Peace River and Charlotte Harbor: Port Charlotte, Fla., Environmental Quality Laboratory, Inc., $232 \mathrm{p}$.

Hammett, K.M., 1988, Land use, water use, streamflow, and water-quality characteristics of the Charlotte Harbor inflow area, Florida: U.S. Geological Survey Open-File Report 87-472, 144 p.

Hughes, G.H., 1978, Runoff from hydrologic units in Florida: Florida Bureau of Geology Map Series 81.

Lewelling, B.R., and Belles, R.G., 1986, Potentiometric surface of the Upper Floridan aquifer, west-central Florida, September 1986: U.S. Geological Survey Open-File Report 86-603, 1 sheet.

Pilson, M.E.Q., 1985, On the residence time of water in Narragansett Bay: Estuaries, v. 8, no. 1, p. 2-14.

Wilson, W.E., 1977, Ground-water resources of De Soto and Hardee Counties, Florida: Florida Bureau of Geology Report of Investigations 83, $102 \mathrm{p}$. 